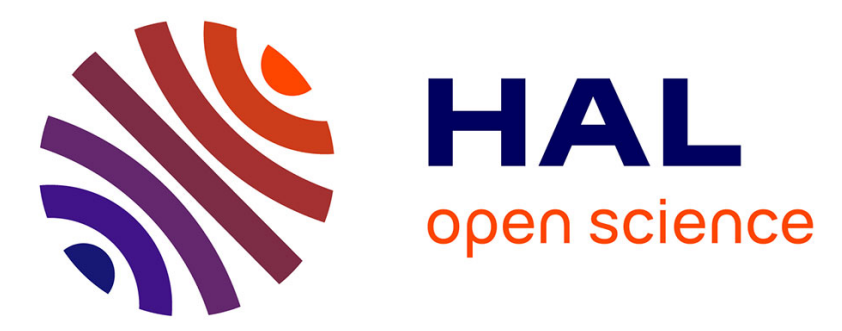

\title{
Novel $\beta$-keto-enol Pyrazolic Compounds as Potent Antifungal Agents. Design, Synthesis, Crystal Structure, DFT, Homology Modeling, and Docking Studies
}

Said Tighadouini, Smaail Radi, Farid Abrigach, Redouane Benabbes, Driss

Eddike, Monique Tillard

\section{To cite this version:}

Said Tighadouini, Smaail Radi, Farid Abrigach, Redouane Benabbes, Driss Eddike, et al.. Novel $\beta$-keto-enol Pyrazolic Compounds as Potent Antifungal Agents. Design, Synthesis, Crystal Structure, DFT, Homology Modeling, and Docking Studies. Journal of Chemical Information and Modeling, 2019, 59 (4), pp.1398-1409. 10.1021/acs.jcim.8b00828 . hal-02117223

\section{HAL Id: hal-02117223 \\ https://hal.science/hal-02117223}

Submitted on 23 Nov 2020

HAL is a multi-disciplinary open access archive for the deposit and dissemination of scientific research documents, whether they are published or not. The documents may come from teaching and research institutions in France or abroad, or from public or private research centers.
L'archive ouverte pluridisciplinaire HAL, est destinée au dépôt et à la diffusion de documents scientifiques de niveau recherche, publiés ou non, émanant des établissements d'enseignement et de recherche français ou étrangers, des laboratoires publics ou privés. 


\title{
Novel $\beta$-keto-enol Pyrazolic Compounds as Potent Antifungal Agents. Design, Synthesis, Crystal Structure, DFT, Homology Modeling and Docking Studies
}

\author{
Said Tighadouini, ${ }^{\dagger}$ Smaail Radi, ${ }^{*},{ }^{\dagger}$ Farid Abrigach, $*, \dagger$ Redouane Benabbes, ${ }^{\dagger}$ Driss
} Eddike, ${ }^{\S}$ and Monique Tillard "

${ }^{\dagger}$ Laboratory of Applied Chemistry \& Environment, Faculty of Sciences, Mohammed First University, 60000 Oujda, Morocco.

Laboratory of Biochemistry, Faculty of Sciences, Mohammed First University, 60000 Oujda, Morocco.

${ }^{\S}$ Laboratory of Mineral Solid and Analytical Chemistry, Faculty of Sciences, Mohammed First University, 60000 Oujda, Morocco.

"ICGM, UMR 5253, CNRS, Université de Montpellier, ENSCM, Montpellier, France.

*Correspondence: s.radi@ ump.ac.ma (S. Radi); abrigach.farid@live.fr (F. Abrigach); Tel.: +212-536-500-601/02; Fax: +212-536-500-603

\begin{abstract}
A new family of promising inhibitors bearing $\beta$-keto-enol functionality with greatly improved pharmacophore properties has prepared. Herein, a series of novel derivatives of $\beta$-keto-enol group embedded with pyrazolic moiety has been designed and synthesized via a one-step procedure using mixed Claisen condensation in the attempt to develop potential antifungal agents. The structures of the synthesized compounds were confirmed by elemental analysis, FT-IR, ESI/LC-MS, ${ }^{1} \mathrm{H}$ and ${ }^{13} \mathrm{C}$ NMR. In addition, X-ray diffraction analysis (XRD) was used to determine the single crystal structure of compound 10. All the newly compounds have been evaluated for their in vitro antifungal and antibacterial activities. Interestingly, the results indicate that most of the compounds display notable antifungal activity close to that of the benomyl fungicide taken as the standard drug. For the most active compound and for benomyl, a correlation has been evidenced between the experimental antifungal activity and the theoretical predictions by DFT calculations and molecular docking against Fgb1 protein.
\end{abstract}

Keywords: Synthesis; Keto-enols; Pyrazole; Crystal structure; DFT calculations; Homology modelling; Molecular docking; Antifungal activity. 


\section{Introduction}

Compounds bearing $\beta$-keto-enol functionality are well established in the world of medicinal chemistry as important biologically effective drugs. ${ }^{1-2}$ Extensive research over the last decade indicates that this compound's family possesses potent anti-HIV properties such as: the S-1360 (designed by Shionogi, Ltd) ${ }^{3}$ and the L-708,906 (designed by Merck Research Laboratories) ${ }^{4}$ (Figure 1). This kind of compounds also inhibits the proliferation of cancer cells, such as the 5-CITEP, which designed by the National Cancer Institute, ${ }^{3}$ and of the influenza virus. ${ }^{5}$

It should be noted that the natural product, the curcumin (Figure 1), and its derivatives, with similar $\beta$-keto-enol pharmacophore site, is of high importance regarding its biological properties. Actually, this natural product presents the main active ingredient of the plant Curcuma longa ${ }^{6}$ Curcumin has been reported to possess strong antioxidant activity, ${ }^{7}$ it acts on several reactive oxygen and nitrogen species including hydroxyl radicals, superoxide anion radicals as well as nitrogen dioxide radicals. ${ }^{8}$ Curcumin had also shown interesting anticancer activity in various cell lines and animal models, due to its capacity to bind to different proteins and to acts by different mechanisms. ${ }^{9-13}$ Additionally, It exerts antiangiogenic, antimalarial, anti-HIV, anti-inflammatory and anti-tubercular activities. ${ }^{14-16}$

The main advantage of these molecules to be active against all virus genotypes and drugresistant variants is due essentially to the presence of a high potential $\beta$-keto-enol pharmacophore site. The biological responses of this moiety may be explained by its facility to penetrate into the vessel walls and plasma cell membranes, its strong interaction with the amino acid residues of active sites, its capability to chelate with metals in biological processes, and also its reaction with oxygen or with cell macromolecules resulting in oxidative stress, in complex immune responses to hapten-conjugate adducts and in modulation of genes expression. $^{17}$

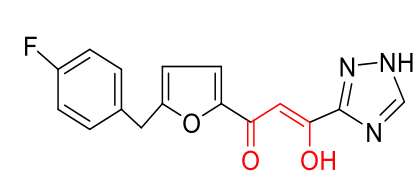

S-1360

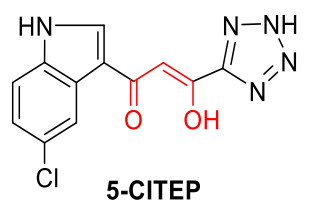

5-CITEP

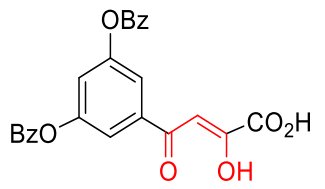

L-708,906

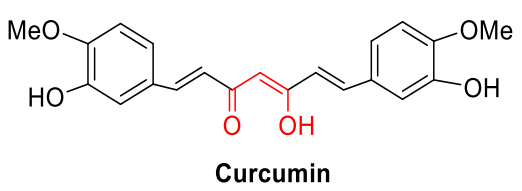

Figure 1. Structures of some drugs contain keto-enol functionality. 
Recently, several analogous compounds containing the $\beta$-keto-enol pharmacophore, were synthetized , such as the keto-enol tetrazoles and triazoles as anti-HCV agents, ${ }^{18}$ the triazolylketo-enol calix[4]arene as potent integrase strand transfer inhibitory activity, ${ }^{19}$ and coumarinyl chalcones as high selective agents for the breast cancer cell lines, ${ }^{20}$ etc.

On the other part, various computational approaches have been developed in the last years and used across the whole drug discovery process in order to reduce the cost and the time needed to develop and discovery a new drug. Particularly, molecular docking study becomes one of the most popular theoretical tools used to screen and compare wide libraries of compounds especially in the field of medicinal chemistry. The main objective of this technique is to provide an atomistic insight into molecular recognition by predicting the ability of a molecule to bind to the active site of a protein. Based on computational methods, it models the conformation and the orientation of a molecule interacting with a receptor site. The method has experienced rapid growth and many improvements over the last two decades and the number of publications associated with molecular docking studies has increased enormously. ${ }^{21}$

In continuation of our recent works in the field of the synthesis of novel $\beta$-keto-enol heterocyclic derivatives through efficient and simple routes and of the study of their biological activities, ${ }^{17,22-31}$ we report in the present investigation on the synthesis and the properties of a novel series of pyrazoles with the $\beta$-keto-enol functionality as powerful moieties especially in fungal activity. To the best of our knowledge, this is the first real study aiming to develop diversified structures of keto-enol pyrazoles.

\section{Materials and Methods}

\subsection{General Information}

All the chemical reagents used in this study were of analytical grade (Aldrich, purity > 99\%). Melting points were measured with a BUCHÏ 510 m.p. apparatus. ${ }^{1} \mathrm{H}$ and ${ }^{13} \mathrm{C}$ NMR spectra were recorded on a Bruker AC 300 spectrometer operating at $300 \mathrm{MHz}$ for proton and 75.47 for carbon nuclei. Molecular weights were determined using a JEOL JMS DX-300 mass spectrometer. Elemental analysis was performed by Microanalysis Central Service (CNRS). Infrared (IR) spectra were acquired on a Shimadzu infrared spectrophotometer using the $\mathrm{KBr}$ disc technique. X-ray diffraction data collection was carried out on the four-circle Oxford Xcalibur diffractometer (Mo-K $\alpha$ radiation, $\lambda=0.71073 \AA$ ). The in vitro antibacterial and antifungal activity was tested by the agar diffusion technique. 


\subsection{Synthesis of the $\beta$-keto-enol pyrazole derivatives}

The $\beta$-keto-enol pyrazole derivatives studied in this paper were prepared according to the experimental procedure described in our previous work. ${ }^{17}$ briefly, a $12.01 \mathrm{mmol}$ of pyrazole carboxylate dissolved in $25 \mathrm{~mL}$ of toluene was slowly added to a suspension of sodium (15.21 $\mathrm{mmol})$ in $20 \mathrm{~mL}$ of toluene; then a toluene solution $(10 \mathrm{~mL})$ of aryl methyl ketones $(12.01$ mmol) was added at $0{ }^{\circ} \mathrm{C}$. After stirring at room temperature for 2 days, the precipitate formed was filtered off, washed with toluene, dissolved in water and neutralized with acetic acid to $\mathrm{pH}$ 5. The organic layer obtained after an extraction with $\mathrm{CH}_{2} \mathrm{Cl}_{2}$, was dried over anhydrous sodium sulfate and concentrated in vacuo. Filtration of the obtained crude through silica using $\mathrm{CH}_{2} \mathrm{Cl}_{2} / \mathrm{MeOH}$ as eluent followed by recrystallization from methanol (95\%) afforded the desired products 1-10 as solids in acceptable yields.

\section{(Z)-1-(1,5-dimethyl-1H-pyrazol-3-yl)-3-hydroxy-3(2-methoxyphenyl)prop-2-en-1-one (1).}

Yellow crystal; yield: $26 \%$; M.p. $80^{\circ} \mathrm{C} ; R_{f}=0.87\left(\mathrm{CH}_{2} \mathrm{Cl}_{2} / \mathrm{MeOH} 9 / 1\right) /$ silica. IR $\left(\mathrm{KBr}, \mathrm{cm}^{-1}\right)$ : $v(\mathrm{OH})=3433 \mathrm{~cm}^{-1} ; v(\mathrm{C}=\mathrm{O})=1675 \mathrm{~cm}^{-1} ; v(\mathrm{C}=\mathrm{C}$ enolic $)=1530 \mathrm{~cm}^{-1} ;{ }^{1} \mathrm{H} \mathrm{NMR}\left(\mathrm{CDCl}_{3}\right): \delta 2.48$ (s, 3H, Pz-CH $)$ ) 3.62 (s, 3H, $\left.\mathrm{CH}_{3}-\mathrm{N}\right): 3.89$ (s, 3H, O-CH3);4.63 (s, 0.1H, keto, $\mathrm{CH}_{2}$ ); 6.50 (s, 1H, Pz-H); 6.60 (s, 0.9H, enol, C-H); 6.99 (m, 2H, Ar-H $) ; 7.07$ (m, 2H, Ar-H $) ; 7.47$ (m, 2H, Ar-H 4$) 7.60\left(\mathrm{~m}, 2 \mathrm{H}, \mathrm{Ar}-\mathrm{H}_{6}\right) .{ }^{13} \mathrm{C}^{\mathrm{NMR}}\left(\mathrm{CDCl}_{3}\right): \delta 11.14\left(1 \mathrm{C}, \mathrm{Pz}_{-} \mathrm{CH}_{3}\right) ; 37.30\left(1 \mathrm{C}, \underline{\mathrm{C}} \mathrm{H}_{3}-\mathrm{N}\right)$; 49.29 (1C, keto $\left.\mathrm{CH}_{2}\right)$; 56.30 (1C, o-OCH $\left.3-\mathrm{Ar}\right)$; 98.50 (1C, enol C-H); 106.34 (1C,= $\underline{\mathrm{C}} \mathrm{H}-$ $\mathrm{Pz}) ; 112.87$ (1C, Ar-C1); 120.47 (1C, $\left.\mathrm{Ar}_{-} \mathrm{C}_{3}\right) ; 121.07$ (1C, Ar-C $)$; 121.76 (1C, Ar-C 6 ); 158.51 (1C, Ar- $\left.\mathrm{C}_{2}\right) ; 184.07$ (1C, $\left.\underline{\mathrm{C}}-\mathrm{OH}\right) ; 190.17$ (1C, $\left.\underline{\mathrm{C}}=\mathrm{O}\right)$. Anal. calcd for $\mathrm{C}_{15} \mathrm{H}_{16} \mathrm{~N}_{2} \mathrm{O}_{3}: \mathrm{C} 66.16, \mathrm{H}$ 5.92, N 10.29. Found C 66.12, H 5.90, N 10.35; $/ z / z: 273.06(\mathrm{M}+\mathrm{H})^{+}$.

(Z)-1-(1,5-dimethyl-1H-pyrazol-3-yl)-3-hydroxy-3(3-methoxyphenyl)prop-2-en-1-one (2). Yellow crystal; yield: 32\%; M.p. $106^{\circ} \mathrm{C} ; R_{f} .0 .27\left(\mathrm{CH}_{2} \mathrm{Cl}_{2} / \mathrm{MeOH} 9 / 1\right) /$ silica, IR $\left(\mathrm{KBr}, \mathrm{cm}^{-1}\right)$ : $v(\mathrm{OH})=3430 \mathrm{~cm}^{-1} ; v(\mathrm{C}=\mathrm{O})=1676 \mathrm{~cm}^{-1} ; v(\mathrm{C}=\mathrm{C}$ enolic $)=1529 \mathrm{~cm}^{-1} .{ }^{1} \mathrm{H}$ NMR (DMSO-d6): $\delta$ 2.47 (s, 3H, Pz-CH 3$) ; 3.77$ (s, 3H, $\mathrm{CH}_{3}-\mathrm{N}$ ): 3.82 (s, 3H, O-CH 3 ); 4.54 (s, 0.1H, keto, $\mathrm{CH}_{2}$ ); 6.51 (s, 1H, Pz-H); 6.65 (s, 0.9H, enol, C-H); 6.93 (m, 2H, Ar-H4); 7.02 (m, 2H, Ar- $\left.\mathrm{H}_{2}\right) ; 7.87$ (m, $\left.2 \mathrm{H}, \mathrm{Ar}-\mathrm{H}_{6}\right) ; 7.95$ (m, 2H, Ar-H$) .{ }^{13} \mathrm{C}$ NMR (DMSO-d6): 11.14 (1C, Pz-CH $)$; 37.26 (1C, $\mathrm{CH}_{3}-$ $\mathrm{N}) ; 49.21$ (1C, keto $\mathrm{CH}_{2}$ ); 56.02 (1C, p-OCH $\left.3-\mathrm{Ar}\right)$; 92.23 (1C, enol C-H); 106.14 (1C,= $\underline{\mathrm{CH}}-$ $\mathrm{Pz}) ; 114.62$ (2C, $\left.\mathrm{Ar}-\mathrm{C}_{3,5}\right) ; 129.64$ (2C, $\left.\mathrm{Ar}_{-} \mathrm{C}_{2,6}\right) ; 181.73$ (1C, $\left.\underline{\mathrm{C}}-\mathrm{OH}\right) ; 182.87$ (1C, $\left.\underline{\mathrm{C}}=\mathrm{O}\right)$. Anal. calcd for $\mathrm{C}_{15} \mathrm{H}_{16} \mathrm{~N}_{2} \mathrm{O}_{3}$ : C 66.16, H 5.92, N 10.29. Found C 66.11, H 5.88, N 10.32; m/z: 273.06 $(\mathrm{M}+\mathrm{H})^{+}$. 
(Z)-3-(4-bromophenyl)-1-(1,5-dimethyl-1H-pyrazol-3-yl)-3-hydroxyprop-2-en-1-one (5). Brown powder; yield: 32\%; M.p. $150^{\circ} \mathrm{C} ; R_{f} .0 .93\left(\mathrm{CH}_{2} \mathrm{Cl}_{2} / \mathrm{MeOH} 9 / 1\right) /$ silica. IR $\left(\mathrm{KBr}, \mathrm{cm}^{-1}\right)$ : $v(\mathrm{OH})=3448 ; v(\mathrm{C}=\mathrm{O})=1611 ; v($ enolic $\mathrm{C}=\mathrm{C})=1565 ;{ }^{1} \mathrm{H}$ NMR $\left(\mathrm{CDCl}_{3}\right): \delta 2.30(\mathrm{~s}, 3 \mathrm{H}, \mathrm{Pz}-$ $\left.\mathrm{CH}_{3}\right) ; 3.63$ (s, 3H, $\left.\mathrm{CH}_{3}-\mathrm{N}\right): 3.76$ (s, 0.1H, keto, $\mathrm{CH}_{2}$ ); 6.52 (s, 1H, Pz-H); 6.69 (s, 0.9H, enol, $\mathrm{C}-\mathrm{H}) ; 7.72\left(\mathrm{~m}, 2 \mathrm{H}, \mathrm{Ar}-\mathrm{H}_{3,5}\right) ; 7.85\left(\mathrm{~m}, 2 \mathrm{H}, \mathrm{Ar}-\mathrm{H}_{2,6}\right) .{ }^{13} \mathrm{C} \mathrm{NMR}\left(\mathrm{CDCl}_{3}\right): \delta 11.38\left(1 \mathrm{C}, \mathrm{Pz}_{-} \mathrm{CH}_{3}\right)$; $37.04\left(1 \mathrm{C}, \underline{\mathrm{CH}}_{3}-\mathrm{N}\right) ; 48.78$ (1C, keto $\left.\mathrm{CH}_{2}\right) ; 94.56$ (1C, enol C-H); $106.45(1 \mathrm{C},=\underline{\mathrm{CH}}-\mathrm{Pz}) ; 121.94$ (1C, Ar- $\left.\mathrm{C}_{4}\right) ; 126.09$ (2C, Ar-C 3,5$) ; 129.22\left(2 \mathrm{C}, \mathrm{Ar}-\mathrm{C}_{2,6}\right) ; 180.54(1 \mathrm{C}, \underline{\mathrm{C}}-\mathrm{OH}) ; 183.59(1 \mathrm{C}, \underline{\mathrm{C}}=\mathrm{O})$. Anal. calcd for $\mathrm{C}_{14} \mathrm{H}_{13} \mathrm{BrN}_{2} \mathrm{O}_{2}$ : C 52.36, H 4.08, N 8.72. Found C 52.27, H 4.03, N 8.81; $m / z$ : $321(\mathrm{M}+\mathrm{H})^{+}$.

(Z)-1-(1,5-dimethyl-1H-pyrazol-3-yl)-3-hydroxy-3-(thiophen-2-yl)prop-2-en-1-one

(6). Brown powder; yield: $30 \%$; M.p. $110^{\circ} \mathrm{C} ; R_{f}: 0.42\left(\mathrm{CH}_{2} \mathrm{Cl}_{2} / \mathrm{MeOH} 9 / 1\right) /$ silica. IR $\left(\mathrm{KBr}, \mathrm{cm}^{-1}\right)$ : $v(\mathrm{OH})=3434 ; v(\mathrm{C}=\mathrm{O})=1672 ; v(\mathrm{C}=\mathrm{C}$ enolic $)=1531 ;{ }^{1} \mathrm{H}$ NMR $($ DMSO-d6) $: 2.30(\mathrm{~s}, 3 \mathrm{H}, \mathrm{Pz}-$ $\left.\mathrm{CH}_{3}\right) ; 3.84\left(\mathrm{~s}, 3 \mathrm{H}, \mathrm{CH}_{3}-\mathrm{N}\right) ; 4.56$ (s, 0.1H, keto, $\left.\mathrm{CH}_{2}\right) ; 6.58(\mathrm{~s}, 1 \mathrm{H}, \mathrm{Pz}-\mathrm{H}) ; 6.80$ (s, 0.9H, enol,

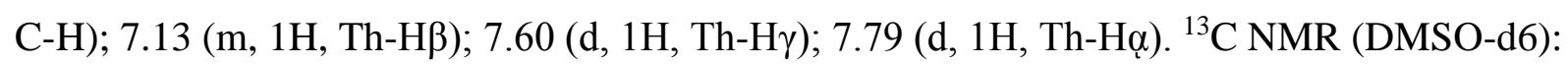
11.41 (1C, Pz-CH 3$) ; 37.00\left(1 \mathrm{C}, \underline{\mathrm{CH}}_{3}-\mathrm{N}\right) ; 46.76$ (1C, keto $\left.\mathrm{CH}_{2}\right) ; 92.89$ (1C, enol C-H); 106.11 $(1 \mathrm{C},=\underline{\mathrm{C}} \mathrm{H}-\mathrm{Pz}) ; 128.32$ (1C, Th-H $\gamma) ; 130.20$ (1C, Th-C $\beta)$; 132.16 (1C, Th-C $\alpha$ ); 140.46 (1C, Th$\mathrm{C} \varepsilon) ; 177.87$ (1C, $\underline{\mathrm{C}}-\mathrm{OH}) ; 180.96(1 \mathrm{C}, \underline{\mathrm{C}}=\mathrm{O})$. Anal. Calcd. for $\mathrm{C}_{12} \mathrm{H}_{12} \mathrm{~N}_{2} \mathrm{O}_{2} \mathrm{~S}: \mathrm{C}$ 58.05, H 4.87, N 11.28. Found: C 58.02, H 4.99, N 11.31. $\mathrm{m} / \mathrm{z}: 249.06(\mathrm{M}+\mathrm{H})^{+}$.

(Z)-1-(1,5-dimethyl-1H-pyrazol-3-yl)-3-hydroxy-3-(thiophen-3-yl)prop-2-en-1-one

White powder; yield $25 \%$, M.p. $176^{\circ} \mathrm{C}$; Rf: $0.22\left(\mathrm{CH}_{2} \mathrm{Cl}_{2} / \mathrm{MeOH} 9 / 1\right) /$ silica. IR $\left(\mathrm{KBr}, \mathrm{cm}^{-1}\right)$ : $v(\mathrm{OH})=3434 ; v(\mathrm{C}=\mathrm{O})=1672 ; v(\mathrm{C}=\mathrm{C}$ enolic $)=1531 ;{ }^{1} \mathrm{H}$ NMR $($ DMSO-d6) $: 2.49(\mathrm{~s}, 3 \mathrm{H}, \mathrm{Pz}-$ $\left.\mathrm{CH}_{3}\right) ; 3.36$ (s, 0.1H, keto, $\left.\mathrm{CH}_{2}\right) ; 3.74\left(\mathrm{~s}, 3 \mathrm{H}, \mathrm{CH}_{3}-\mathrm{N}\right) ; 6.43(\mathrm{~s}, 1 \mathrm{H}, \mathrm{Pz}-\mathrm{H}) ; 7.16$ (s, 0.9H, enol, $\mathrm{C}-\mathrm{H}) ; 7.36$ (d, 1H, Th-H $\alpha$ ); 7.48 (m, 1H, Th-H $\beta) ; 7.83$ (d, 1H, Th-H $\gamma$ ). ${ }^{13} \mathrm{C}$ NMR (DMSO-d6): 11.04 (1C, Pz-CH 3$) ; 37.04\left(1 \mathrm{C}, \underline{\mathrm{CH}}_{3}-\mathrm{N}\right) ; 47.76$ (1C, keto $\left.\mathrm{CH}_{2}\right) ; 96.23$ (1C, enol C-H); 108.14 $(1 \mathrm{C},=\underline{\mathrm{CH}}-\mathrm{Pz}) ; 123.32$ (1C, Th-C $\beta$ ); 127.46 (1C, Th-Ce); 128.16 (1C, Th-C $\alpha$ ); 141.20 (1C, Th$\mathrm{H} \gamma) ; 176.97$ (1C, $\underline{\mathrm{C}}-\mathrm{OH}) ; 179.25$ (1C, $\underline{\mathrm{C}}=\mathrm{O})$. Anal. Calcd. for $\mathrm{C}_{12} \mathrm{H}_{12} \mathrm{~N}_{2} \mathrm{O}_{2} \mathrm{~S}: \mathrm{C}$ 58.05, H 4.87, N 11.28. Found: C 57.95, H 4.92, N 11.35. $\mathrm{m} / \mathrm{z}: 249.06(\mathrm{M}+\mathrm{H})^{+}$.

\section{(Z)-1-(1,5-dimethyl-1H-pyrazol-3-yl)-3-hydroxy-3-(pyridine-2-yl)prop-2-en-1-one}

(9).

Brown powder; yield 41\%; M.p. $189^{\circ} \mathrm{C}$; Rf: $0.47\left(\mathrm{CH}_{2} \mathrm{Cl}_{2} / \mathrm{MeOH} 9 / 1\right) /$ silica. IR $\left(\mathrm{KBr}, \mathrm{cm}^{-1}\right)$ : $v(\mathrm{OH})=3431 ; v(\mathrm{C}=\mathrm{O})=1672 ; v(\mathrm{C}=\mathrm{C}$ enolic $)=1529 ;{ }^{1} \mathrm{H}$ NMR (DMSO-d6) $2.29(\mathrm{~s}, 3 \mathrm{H}, \mathrm{Pz}-$ $\left.\mathrm{CH}_{3}\right) ; 3.85$ (s, 3H, $\left.\mathrm{CH}_{3}-\mathrm{N}\right) ; 3.72$ (s, 0.1H, keto, $\left.\mathrm{CH}_{2}\right) ; 6.66(\mathrm{~s}, 1 \mathrm{H}, \mathrm{Pz}-\mathrm{H}) ; 7.53$ (s, 0.9H, enol,

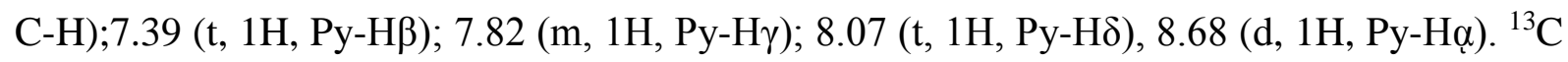


NMR (DMSO-d6): 11.39 (1C, Pz-CH 3$) ; 37.04$ (1C, $\left.\underline{C H}_{3}-\mathrm{N}\right)$; 48.78 (1C, keto $\left.\mathrm{CH}_{2}\right)$; 94.56 (1C, enol C-H); 106.45 (1C,= $\underline{\mathrm{CH}}-\mathrm{Pz}) ; 121.94$ (1C, Py-C $)$; 126.10 (1C, Py-Cß); 137.02(1C, PyC $\gamma$ ); 149.47 (1C, Py-C $\alpha$ ); 152.40 (1C, Py-Ce); 180.04 (1C, C-OH), 183.78 (1C, C=O). Anal. Calcd. for $\mathrm{C}_{13} \mathrm{H}_{13} \mathrm{~N}_{3} \mathrm{O}_{2}$ : C 64.19, H 5.39, N 17.27. Found: C 64.08, H 5.27, N 17.38. m/z: 244.10 $(\mathrm{M}+\mathrm{H})^{+}$.

\section{(Z)-1-(1,5-dimethyl-1H-pyrazol-3-yl)-3-(naphthalene-1-yl)prop-2-en-1-one (10).}

Pale-yellow crystal, yield 27\%, M.p. $159^{\circ} \mathrm{C}$; Rf: $0.91\left(\mathrm{CH}_{2} \mathrm{Cl}_{2} / \mathrm{MeOH} 9 / 1\right) /$ silica. $\mathrm{IR}\left(\mathrm{KBr}, \mathrm{cm}^{-}\right.$ $\left.{ }^{1}\right): v(\mathrm{OH})=3433 ; v(\mathrm{C}=\mathrm{O})=1675 ; v(\mathrm{C}=\mathrm{C}$ enolic $)=1534 ;{ }^{1} \mathrm{H}$ NMR (DMSO-d6): 2.34 (s, 3H,

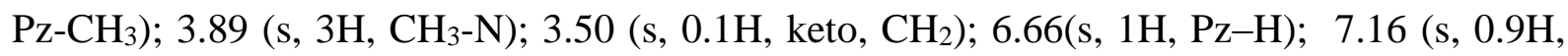
enol, C-H); 7.56 (m, 1H, Ar-H3); 7.89 (m, 2H, Ar- $\left.\mathrm{H}_{2,7}\right) ; 7.97$ (m, 2H, Ar-H 1,6$) ; 8.04$ (m, 1H, Ar-

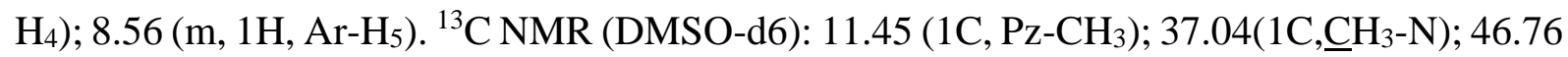
(1C, keto $\left.\mathrm{CH}_{2}\right)$; 93.70 (1C, enol C-H); 106.36 (1C,= $\left.\underline{\mathrm{CH}}-\mathrm{Pz}\right) ; 123.44$ (1C, $\left.\mathrm{Ar}_{-} \mathrm{C}_{1}\right) ; 126.78$ (1C,

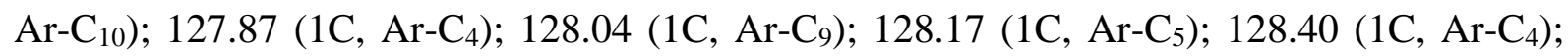
$128.63\left(1 \mathrm{C}, \mathrm{Ar}-\mathrm{C}_{3}\right) ; 129.45$ (1C, $\left.\mathrm{Ar}-\mathrm{C}_{6}\right) ; 132.38$ (1C, $\left.\mathrm{Ar}-\mathrm{C}_{1}\right) ; 138.39$ (1C, $\left.\mathrm{Ar}-\mathrm{C}_{1}\right) ; 182.03(1 \mathrm{C}$, $\underline{\mathrm{C}}-\mathrm{OH}) ; 183.25$ (1C, $\underline{\mathrm{C}}=\mathrm{O})$. Anal. Calcd. for $\mathrm{C}_{18} \mathrm{H}_{16} \mathrm{~N}_{2} \mathrm{O}_{2}$ : C 73.95, H 5.52, N 9.58. Found: C 73.91, H 5.40, N 9.72. $\mathrm{m} / \mathrm{z}: 293.12(\mathrm{M}+\mathrm{H})^{+}$.

\subsection{X-ray diffraction analysis}

Crystals with fairly regular shape were selected using a stereomicroscope equipped with a polarizing filter. The CrysAlis software ${ }^{32}$ has been used for data reduction and for unit cell determination by least-squares from the 5522 (including symmetry equivalent and redundant) collected reflections at $173 \mathrm{~K}$ within the complete diffraction sphere (Mo-K $\alpha$ radiation, $\lambda=$ $0.71073 \AA$ A). Full-matrix least-squares refinements on $\mathrm{F}^{2}$ used a set of 3076 unique reflections of which 2393 are observed according to the criterion $\mathrm{I}>2 \sigma(\mathrm{I})$. The diffracted intensities were corrected for Lorentz and polarization effects. Structure has been solved and refined with SHELX-2013 program packages. ${ }^{33}$ Positional and anisotropic displacement parameters were refined for all non- $H$ atoms. The $H$-atoms at keto-enol group, detected in the final Fourier difference, were freely refined while other $H$-atoms were considered with an isotropic displacement parameter equal to 1.2 times (1.5 for terminal $\left.-\mathrm{CH}_{3}\right)$ the $\mathrm{U}_{\text {eq }}$ of the parent atom. The molecular representation is drawn with ORTEP-3 for windows. ${ }^{34}$ 


\subsection{Biological evaluation}

\subsubsection{Antifungal assay}

The in vitro antifungal potential of the prepared compounds against the pathogen fungus Fusarium oxysporum f.sp albedinis (FAO) was determined by the agar diffusion technique. ${ }^{35-36}$ Briefly, potato dextrose agar (PDA) medium was mixed with different volumes (50, 200 and $500 \mu \mathrm{L}$ ) of a DMSO solution of the tested compounds to prepare Petri plates with different concentrations. Thereafter, discs of $6 \mathrm{~mm}$ diameter of the microorganism $(F A O)$ were placed into the middle of these Petri plates. After an incubation at $28{ }^{\circ} \mathrm{C}$ for 7 days, inhibition percentages were calculated and the half-maximal inhibitory concentration (IC50) was determined using a non-linear regression algorithm of the dose - inhibition percentage graph. Benomyl was used as the standard drug (positive control).

\subsubsection{Antibacterial Test}

In accordance with the National Committee for Clinical Laboratory Standards (NCCLS) recommendations. ${ }^{37}$ The antibiotic effect of target compounds $\underline{\mathbf{1}}-\underline{\mathbf{1 0}}$ was assessed against one gram-negative bacterium viz. Escherichia coli and two gram-positive strains viz. Bacillus subtilis and Micrococcus luteus. For assays, test compounds were dissolved in dimethyl sulfoxide (DMSO). Sterile WHATMAN paper discs (6 $\mathrm{mm}$ in diameter) were impregnated with different volumes of each compound and then placed in the middle of Petri plates containing the culture media (Muller-Hinton agar) previously inoculated with overnight cultures of the target strains. After 24 hours of incubation at $37^{\circ} \mathrm{C}$, diameter of inhibition zones around each disc was measured. Gentamicin $\left(1 \mathrm{mg} \cdot \mathrm{mL}^{-1}\right.$ used at $10 \mu \mathrm{L}$ and $\left.20 \mu \mathrm{L}\right)$ was used as standard drug.

\subsection{Computational studies}

\subsubsection{Homology modeling}

Due to the lack of a 3D experimental crystal structure of Fusarium oxysporum Guanine nucleotide-binding protein beta (Fgb1) in the Protein Data Bank (PDB, www.rcsb.org), a homology modeling study was carried out to build a suitable 3D structural model for this protein prior to use in our docking study. This model was constructed as it has been described in our previous paper. ${ }^{38}$ 


\subsubsection{DFT calculations and Molecular docking}

The structures of benomyl and compound 9 (9t and 9p) were drawn in ACD/ChemSketch software. ${ }^{39}$ Their geometries were optimized using density functional theory (DFT) method, at B3LYP level of theory with a 6-31 G (d,p) basis set, provided in the Gaussian 09 package. ${ }^{40}$ The Molecular Electrostatic Potential (MEP) was calculated for the optimized molecules and maps have been generated utilizing the GaussView 05 software. SwissDock server which is a free service was used to perform the docking studies against the generated model of FGB1 protein. ${ }^{41}$ The docking results were then analyzed by the UCSF Chimera molecular viewer. ${ }^{42}$ The protonated form of compound 9 (9p) was determined using "Marvin Sketch version 17.1.30", software. ${ }^{43}$

\section{Results and Discussion}

\subsection{Compounds chemistry}

The main route for the preparation of compounds in this work is given below (Scheme 1). The synthesis of ten target compounds characterized by $\beta$-keto-enol group tethered pyrazole was developed using our method which has been recently described elsewhere. ${ }^{17}$ Indeed, the synthesis is governed by a one-pot in-situ condensation under mild conditions (room temperature, two days). The reaction takes place through stirring a mixture of ketone derivatives and ethyl pyrazole-2-carboxylate using toluene as the solvent and sodium metal as the base. After neutralization to $\mathrm{pH}=5$ of the generated keto-enolate salts using acetic acid, and filtering them through silica using $\mathrm{CH}_{2} \mathrm{Cl}_{2} / \mathrm{MeOH}$ as eluent, the title products were obtained in acceptable yields.

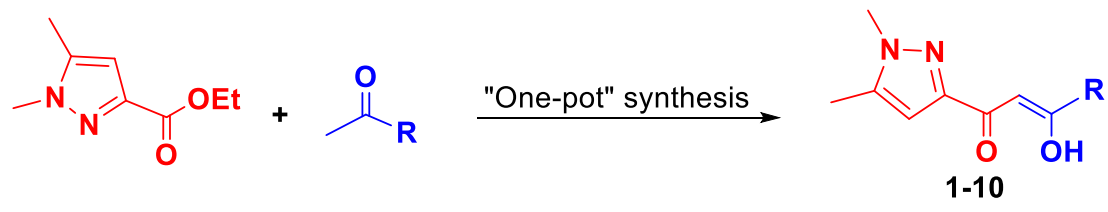

Reagents and conditions: $\mathrm{Na}$, Toluene, rt, 2 days, then acetic acid

Scheme 1. Main route of the synthesis of compounds 1-10.

We would like to emphasize that the desired products have been almost exclusively obtained in the $\beta$-keto-enol tautomer form (> 90\%). In fact, the $\beta$-keto-enol form is greatly favored over the $\beta$-diketone form due to the conjugation effect of the enol with the carbonyl group, and the increase in stability resulting from a strong six-centered intramolecular hydrogen bond. Indeed, the $\beta$-keto-enol interconversion rate (> 90\%) was determined from the NMR spectra by 
integration of the signals associated to the enol $=\mathrm{C}-\mathrm{H}$ and the ketone $\mathrm{CH}_{2}$. We noted the presence of the keto form only as traces visible around $4 \mathrm{ppm}$. In addition, a very small negative signal from $\mathrm{CH}_{2}$ was observed on the DEPT-135 spectra. Finally, crystals were isolated by slow evaporation from methanol for majority of the $\beta$-keto-enol compounds.

Two driving forces are responsible for the formation of the favored keto-enol isomer in solution, these forces have been postulated by Plessis et al. ${ }^{44}$ The first one is that related to the electronic driving force in which the formation of the preferred enol isomer is controlled by the group electronegativity $\left(\chi_{\mathrm{R}}\right)$ of the substituents $\mathrm{R}$ and $\mathrm{R}^{\prime}$ fixed on the $\beta$-diketone $\mathrm{R}^{\prime} \mathrm{COCH}_{2} \mathrm{COR}$. However, this driving force was not found to apply to the $\beta$-keto-enol obtained form. The second force for determining which keto-enol isomer will be favored is the resonance driving force which annuls the electronic driving force when one or the two substituents $\mathrm{R}$ and $\mathrm{R}$ ' are aromatic.

Accordingly, our previously prepared products were exclusively obtained in the $\beta$-keto-enol tautomer form, governed by the resonance driving force, as confirmed by XRD. ${ }^{22-27}$ Herein, as proved by its crystal structure determined from the X-ray diffraction study, compound $\mathbf{1 0}$ was also found to exist with the $\beta$-keto-enol tautomer form.

\subsection{X-ray Crystal Structure Description}

The single crystal structure of $\mathrm{C}_{18} \mathrm{H}_{16} \mathrm{~N}_{2} \mathrm{O}_{2}$ (compound 10) has been determined from $\mathrm{X}$-ray diffraction data. The main crystal data and refinement parameters are reported in Table $\mathbf{1}$ and atom positional and equivalent displacement parameters are given in Table 2. Supplementary information can be obtained free of charge (CCDC 1874191) from the CCDC. ${ }^{45}$ 
Table 1. Crystal data and structure refinement for $\mathrm{C}_{18} \mathrm{H}_{16} \mathrm{~N}_{2} \mathrm{O}_{2}$ (compound 10).

\begin{tabular}{ll}
\hline Formula, $\mathrm{M}, \mathrm{Z}$ & $\mathrm{C}_{18} \mathrm{H}_{16} \mathrm{~N}_{2} \mathrm{O}_{2}, 292.33,2$ \\
Temperature & $173(2) \mathrm{K}$ \\
Space group & Monoclinic, $\mathrm{P} 2_{1}\left(\mathrm{~N}^{\circ} 4\right)$ \\
Lattice & $\mathrm{a}=761.0(1), \mathrm{b}=581.1(1), \mathrm{c}=1634.3(3) \mathrm{pm}$ \\
& $\alpha=90, \beta=93.02(1), \gamma=90^{\circ}$ \\
Crystal & $0.26 \times 0.10 \times 0.07 \mathrm{~mm}$ \\
$\theta$ range & 2.50 to $29.23^{\circ}$ \\
Reflections & 5522 collected $/ 3076$ unique $\left[\mathrm{R}_{\text {int }}=0.0396\right]$ \\
Completeness to $\theta=25.242^{\circ}$ & $99.9 \%$ \\
Data / parameters & $3076 / 209$ \\
Final R indices $[\mathrm{I}>2 \sigma(\mathrm{I})]$ & $\mathrm{R} 1=0.0515, \mathrm{wR} 2=0.0940$ \\
$\mathrm{R}$ indices (all data) & $\mathrm{R} 1=0.0745, \mathrm{wR} 2=0.1041$ \\
$\Delta \rho$ Fourier residuals & $0.168 /-0.170 \mathrm{e} . \AA^{-3}$ \\
\hline
\end{tabular}

The molecular unit $\mathrm{C}_{18} \mathrm{H}_{16} \mathrm{~N}_{2} \mathrm{O}_{2}$ is built with three fragments, a dimethyl pyrazole ring connected through a $\beta$-keto-enol unit to a naphthalene ring (Figure 2). The monoclinic lattice contains two symmetry dependent molecules. In this structure, each fragment is planar as indicated by the RMS deviations of the fitted atoms that are respectively $0.006,0.008$ and 0.019 . Yet, the entire molecule deviates to flatness as reflected by the value of $6.8^{\circ}$ for the dihedral angle between keto-enol and pyrazole fragments and that of $14.8^{\circ}$ between keto-enol and naphthalene groups. The bonds lengths and angles in the molecule are comparable to those found in previous works for other similar compounds..$^{22-27,46}$

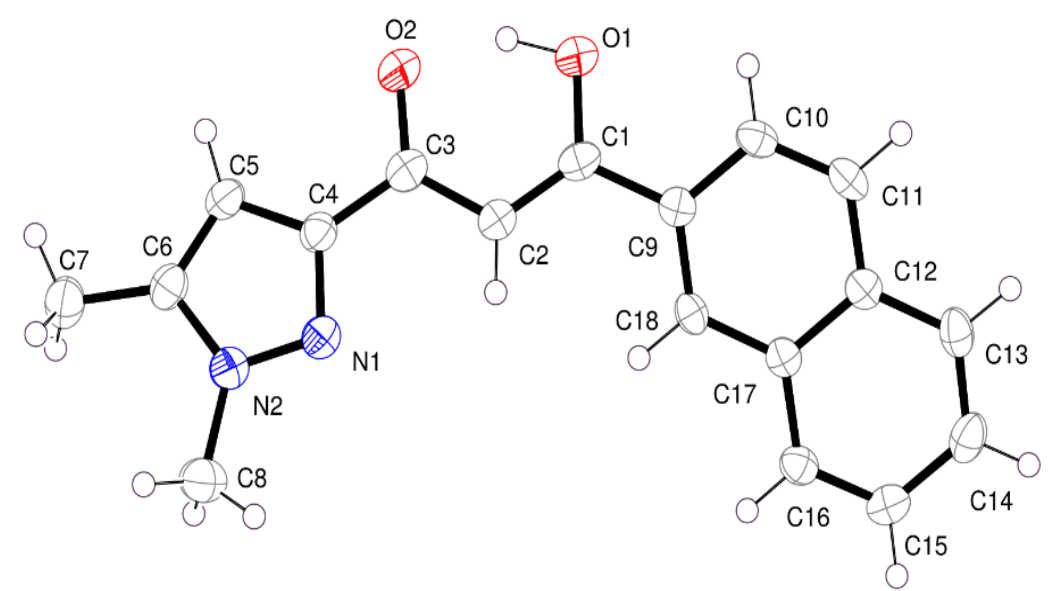

Figure 2. Ortep molecular representation of $\mathrm{C}_{18} \mathrm{H}_{16} \mathrm{~N}_{2} \mathrm{O}_{2}(\mathbf{1 0})$. 
Table 2. Atomic coordinates $\left(\times 10^{4}\right)$ and equivalent displacement parameters $\left(\AA^{2} \times 10^{3}\right)$ for $\mathrm{C}_{18} \mathrm{H}_{16} \mathrm{~N}_{2} \mathrm{O}_{2}$. $\mathrm{U}_{\mathrm{eq}}$ is defined as one third of the trace of the orthogonalized $\mathrm{U}_{\mathrm{ij}}$ tensor.

\begin{tabular}{ccccc}
\hline Atom & $\mathbf{x}$ & $\mathbf{y}$ & $\mathbf{z}$ & $\mathbf{U}_{\mathbf{e q}}$ \\
\hline $\mathrm{O} 1$ & $55(3)$ & $4641(4)$ & $2434(1)$ & $40(1)$ \\
O2 & $285(3)$ & $7380(4)$ & $1272(1)$ & $43(1)$ \\
N1 & $3628(3)$ & $11532(5)$ & $1705(2)$ & $32(1)$ \\
N2 & $4015(3)$ & $13244(5)$ & $1198(2)$ & $33(1)$ \\
C1 & $1256(4)$ & $5878(5)$ & $2845(2)$ & $30(1)$ \\
C2 & $1997(4)$ & $7762(6)$ & $2498(2)$ & $30(1)$ \\
C3 & $1470(4)$ & $8464(5)$ & $1695(2)$ & $31(1)$ \\
C4 & $2266(4)$ & $10454(5)$ & $1319(2)$ & $29(1)$ \\
C5 & $1816(4)$ & $11509(6)$ & $570(2)$ & $31(1)$ \\
C6 & $2949(4)$ & $13298(6)$ & $502(2)$ & $31(1)$ \\
C7 & $3132(4)$ & $15041(7)$ & $-144(2)$ & $40(1)$ \\
C8 & $5476(4)$ & $14790(7)$ & $1411(2)$ & $44(1)$ \\
C9 & $1688(4)$ & $5076(5)$ & $3694(2)$ & $26(1)$ \\
C10 & $1078(4)$ & $2923(5)$ & $3946(2)$ & $29(1)$ \\
C11 & $1386(4)$ & $2202(5)$ & $4735(2)$ & $29(1)$ \\
C12 & $2283(4)$ & $3617(5)$ & $5319(2)$ & $25(1)$ \\
C13 & $2546(4)$ & $2988(6)$ & $6156(2)$ & $32(1)$ \\
C14 & $3404(4)$ & $4416(6)$ & $6701(2)$ & $36(1)$ \\
C15 & $4054(4)$ & $6542(6)$ & $6443(2)$ & $34(1)$ \\
C16 & $3809(4)$ & $7202(5)$ & $5648(2)$ & $28(1)$ \\
C17 & $2912(4)$ & $5792(5)$ & $5068(2)$ & $24(1)$ \\
C18 & $2597(4)$ & $6448(6)$ & $4247(2)$ & $25(1)$ \\
\hline
\end{tabular}

Molecular packing in the monoclinic lattice is such that molecules superimpose along the $\mathrm{a}-$ and b-axes as shown by the projections given in Figure 3. The shorter intermolecular contacts are found at atoms $\mathrm{N} 1$ and $\mathrm{O} 2$ that are involved in weak interactions $\mathrm{N} 1 \cdots \cdot \mathrm{H} 15^{i}-\mathrm{C} 15^{i}$ $\left(2.743 \AA\right.$, angle $\left.130.63^{\circ}\right), \mathrm{O} 2 \cdots \mathrm{H} 5^{i i}-\mathrm{C} 5^{i i}\left(2.630 \AA\right.$, angle $\left.137.17^{\circ}\right)$ and $\mathrm{O} 2 \cdots \cdot \mathrm{H} 7^{i i}-\mathrm{C} 7^{i i}(2.596 \AA$, angle $\left.151.59^{\circ}\right)$ with two neighboring molecules ( $i$ : $\left.1-\mathrm{x}, 1 / 2+\mathrm{y}, 1-\mathrm{z} ; i i:-\mathrm{x},-1 / 2+\mathrm{y},-\mathrm{z}\right)$.
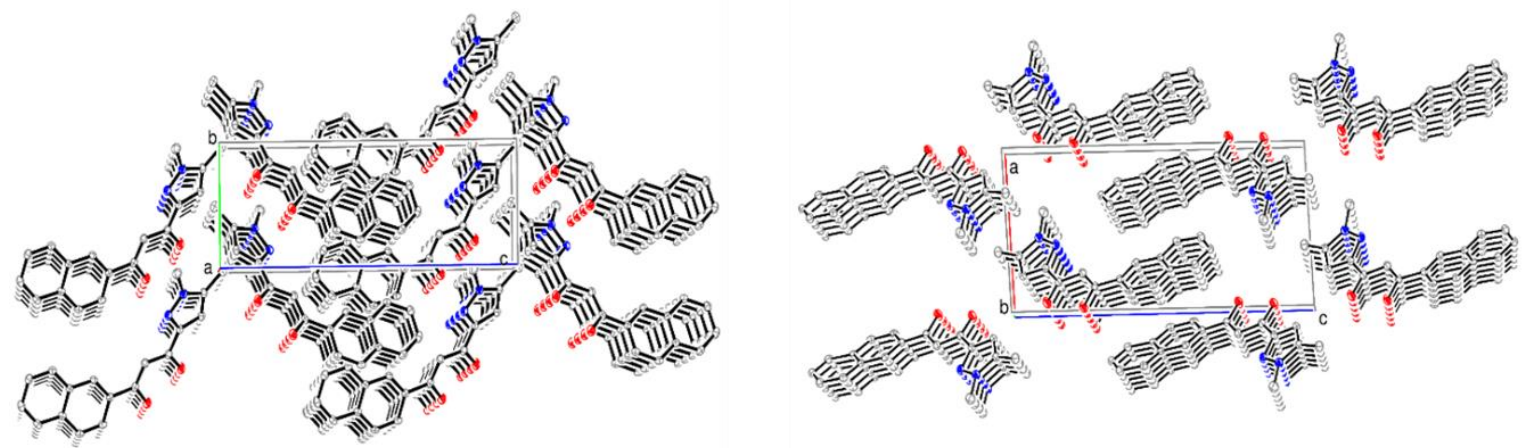

Figure 3. Structural representation of $\mathbf{1 0}$ viewed along (left) a- axis and (right) b-axis of the monoclinic lattice. 


\subsection{Pharmacology}

All the newly synthesized $\beta$-keto-enol pyrazoles were evaluated for their antibacterial activity against three bacterial strains namely Echerichia coli, Bacillus subtilis, and Micrococcus luteus and their antifungal activity against one fungal strain (Fusarium oxysporum f.sp albedinis ) by the agar diffusion method.

Surprisingly, the antimicrobial assay revealed that all the screened compounds possessed very weak or no antibacterial effect against all used strains. They showed inhibition zones less than $7 \mathrm{~mm}$ when it's compared to that of the standard drug gentamicin (inhibition zone equal or greater than $20 \mathrm{~mm}$ ). These findings can be possibly interpreted by the absence of pharmacophore sites which can act as potential and specific features to inhibit the growth of bacteria. ${ }^{47-48}$

In contrast, most of these molecules exhibit potent antifungal activity against $F O A$ in a manner dependent on the dose as indicated in Table 3. Their activity strongly depends on the structure activity relationships (SARs) and shows an interesting influence of the substitution pattern. When looking at the influence of the substituent $\mathrm{R}$, we found that compound $\mathbf{8}$ with the 3-thiophene group and compound $\mathbf{1 0}$ with the 2-naphtalene group lead to the same inhibition percentage of $94 \%$ as the benomyl fungicide. Interestingly, compounds 2 and 9 respectively containing the $m$-OMe- $\mathrm{C}_{6} \mathrm{H}_{4}$ and the 2-pyridine groups even display a slightly better activity of

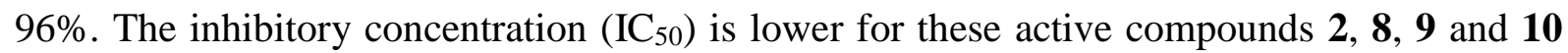
with $\mathrm{IC}_{50}$ values of $71.00,48.00,14.80$ and $53.00 \mu \mathrm{M}$, respectively than the other compounds. Compared to our previous works in this era, these findings present the best obtained results for all the already tested analog products of this family against FOA fungus.

In the context of a marked biological interest for heterocyclic compounds, this suggests that the nature of the $\mathrm{R}$ substituent should be further exploited to modify the properties and to determine the structure activity relationship for this novel class of antifungal agents. 
Table 3. Structures and anti-Fusarium activities of synthetized pyrazole $\beta$-keto-enols.

\begin{tabular}{|c|c|c|c|c|c|}
\hline Comp. & Structure & $\begin{array}{c}\text { Volume } \\
\text { withdrawn } \\
(\mu \mathrm{L}) \\
\end{array}$ & $\begin{array}{c}\text { Diameter of } \\
\text { the strain } \\
(\mathrm{cm})^{*}\end{array}$ & $\begin{array}{c}\text { Inhibition } \\
(\%)\end{array}$ & $\begin{array}{c}\text { IC } \mathbf{5 0}_{\mathbf{5 0}} \\
\mu \mathrm{M}\left(\mu \mathrm{g} . \mathrm{mL}^{-1}\right)\end{array}$ \\
\hline \multirow{3}{*}{1} & & 50 & 3.5 & 30 & \multirow{3}{*}{-} \\
\hline & & 200 & 2.1 & 58 & \\
\hline & & 500 & 1.8 & 64 & \\
\hline \multirow{3}{*}{2} & & 50 & 4.2 & 16 & \multirow{3}{*}{$71.00(260.74)$} \\
\hline & & 200 & 2.8 & 44 & \\
\hline & & 500 & 0.2 & 96 & \\
\hline \multirow{3}{*}{$3^{17}$} & & 50 & 5 & 0 & \multirow{3}{*}{$150.00(550.86)$} \\
\hline & & 200 & 3.6 & 28 & \\
\hline & & 500 & 2.5 & 50 & \\
\hline \multirow{3}{*}{$4^{49}$} & & 50 & 5 & 0 & \multirow{3}{*}{-} \\
\hline & & 200 & 3.8 & 24 & \\
\hline & $\mathrm{H}$ & 500 & 2.7 & 46 & \\
\hline \multirow{3}{*}{5} & & 50 & 4.0 & 20 & \multirow{3}{*}{-} \\
\hline & & 200 & 3.2 & 36 & \\
\hline & $\mathrm{OH}$ & 500 & 2.6 & 48 & \\
\hline \multirow{3}{*}{6} & & 50 & 3.6 & 28 & \multirow{3}{*}{-} \\
\hline & & 200 & 2.4 & 52 & \\
\hline & & 500 & 1.3 & 74 & \\
\hline \multirow{3}{*}{$7^{46}$} & & 50 & 3.5 & 30 & \multirow{3}{*}{-} \\
\hline & & 200 & 2.1 & 58 & \\
\hline & & 500 & 1.2 & 76 & \\
\hline \multirow{3}{*}{8} & & 50 & 3.2 & 36 & \multirow{3}{*}{$48.00(193.31)$} \\
\hline & & 200 & 1.8 & 64 & \\
\hline & & 500 & 0.3 & 94 & \\
\hline \multirow{3}{*}{9} & & 50 & 2.3 & 54 & \multirow{3}{*}{$14.80(60.84)$} \\
\hline & & 200 & 1.2 & 76 & \\
\hline & & 500 & 0.2 & 96 & \\
\hline \multirow{3}{*}{10} & & 50 & 3.2 & 36 & \multirow{3}{*}{$53.00(181.30)$} \\
\hline & & 200 & 2.1 & 58 & \\
\hline & $\mathrm{OH}$ & 500 & 0.3 & 94 & \\
\hline \multirow{3}{*}{\multicolumn{2}{|c|}{ Benomyl }} & 50 & 2.3 & 54 & \multirow{3}{*}{-} \\
\hline & & 200 & 1.1 & 78 & \\
\hline & & 500 & 0.3 & 94 & \\
\hline
\end{tabular}




\subsection{Computational studies}

\subsubsection{DFT calculations}

Calculation of the electronic parameters of a molecule is a well-established tool for the interpretation and the prediction of its reactivity in several types of reactions. The molecular frontier orbital descriptors HOMO (highest occupied molecular orbital) and LUMO (lowest unoccupied molecular orbital) are of great importance in the determination of the reactivity of a molecule. They respectively depict its electron donating and receiving ability. Also, the energy gap ( $\left.\Delta E=E_{\mathrm{LUMO}}-E_{\mathrm{HOMO}}\right)$ is an important parameter which measures the intramolecular charge transfer and the kinetic stability; it has been extensively used to explain the biological activity results. ${ }^{50-51}$ Generally, molecules with a large energy gap are associated with less chemical reactivity, high kinetic stability, while those with a small $\Delta \mathrm{E}$ are more reactive and less stable. ${ }^{52}$

In our case, the HOMO and LUMO energies of the most active antifungal compound i.e. compound 9 and of the standard drug i.e. benomyl were calculated at the DFT/B3LYP/6-31 G (d,p) level of theory to compare and understand their reactivity. The HOMO calculated energy ( $\left.E_{\mathrm{HOMO}}\right)$ is comparable for compound 9 and benomyl. In contrast, their LUMO energies markedly differ by $-1.036 \mathrm{eV}$. The $E_{\mathrm{LUMO}}$ energies are $-1.555 \mathrm{eV}$ for compound 9 and -0.519 $\mathrm{eV}$ for benomyl, leading to values of 4.218 and $5.303 \mathrm{eV}$ for the calculated energy gaps, which means that benomyl is more stable (therefore less active) than compound $\mathbf{9}$. In conclusion, it was observed that the LUMO energy level has a critical effect on the increase in reactivity of compound 9 compared to benomyl. These findings are in good agreement with our experimental results. The shape and the location of LUMO orbital should also be considered, it can be affected by the presence (or not) of electron-donating or withdrawing groups in the molecule. Many investigations revealed that the placement of the LUMO orbitals, along with their energy, can together influence the biological activity. ${ }^{53}$ Here, the representation of the frontier molecular orbital shapes for both molecules (Figure 4) shows that the occupied orbital (HOMO) is mainly localized on the pyridine ring and the $\beta$-keto-enol pharmacophore for compound 9 and on the benzimidazole moiety and the ester function for benomyl. On the contrary, the empty LUMO orbital is delocalized over the entire molecule in both cases. 

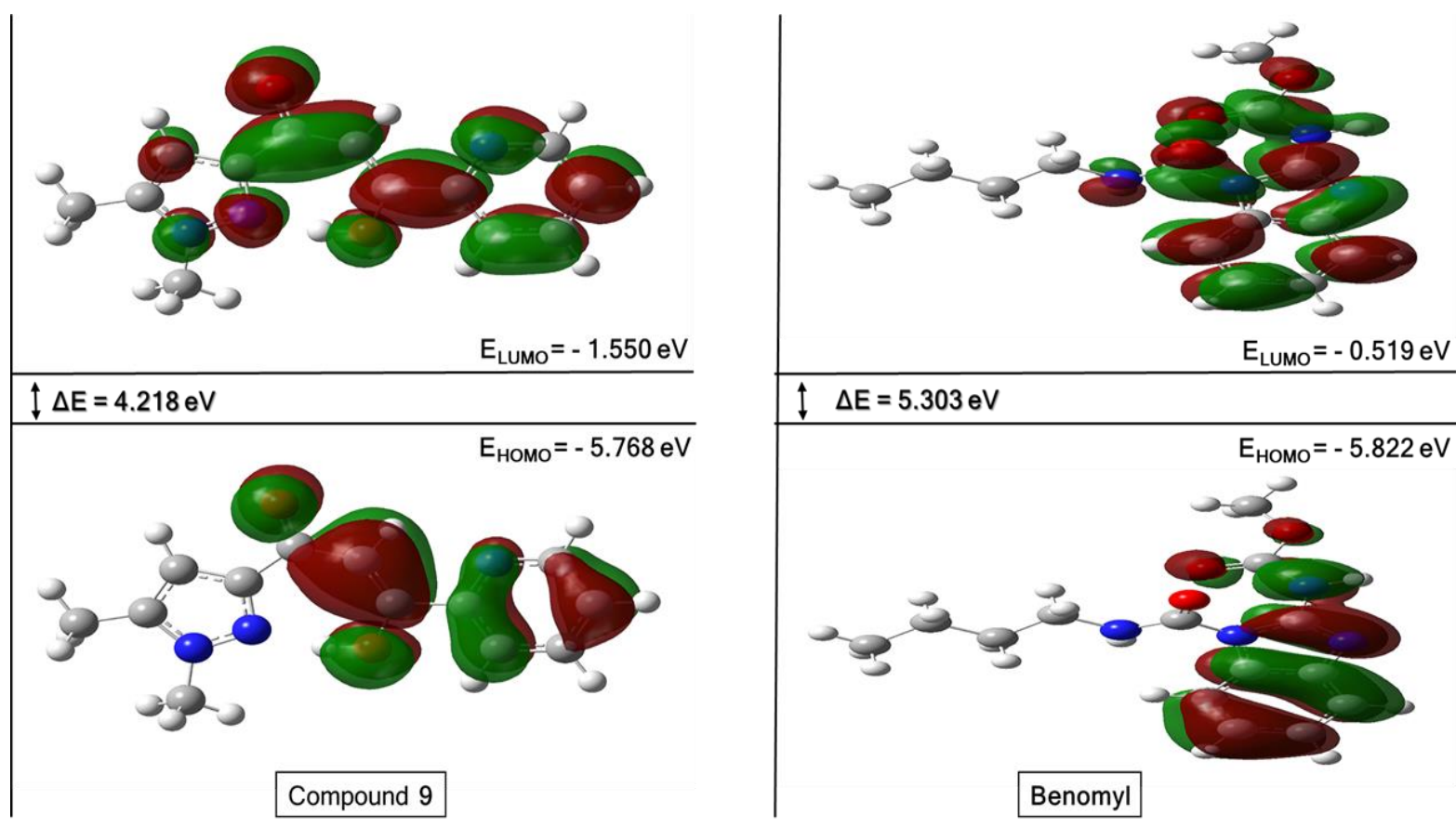

Figure 4. HOMO and LUMO plots of compound 9 and benomyl. Positive and negative phases are shown in red and green colors, respectively.

Additionally, many other quantum chemical parameters can be used as measures of the reactivity of molecules. Their values are generally calculated from the HOMO and LUMO energies. The hardness of a molecule is an important concept to evaluate the stability and reactivity of a species, it defines the resistance towards deformation or polarization of the electron density distribution of a chemical system in an electric field. ${ }^{54}$ This concept can be expressed as chemical hardness $(\eta)$ and softness $(\sigma) .{ }^{55}$ The electronegativity $(\chi)$ is a measure of the power of a molecule to attract electrons whereas the chemical potential $(\mu)$ evaluates the tendency of an electron to escape from the molecule. The ability of a species to accept electrons is quantified by the electrophilicity index. ${ }^{56}$ As a consequence, high chemical hardness values characterize stable compounds with low reactivity while high values for softness, electronegativity, chemical potential and electrophilicity denote less stable hence more reactive compounds. All these indices (Table 4) have been calculated from the computed HOMO and LUMO energies, using the appropriate equations.

The analysis of these parameters clearly reveals a high reactivity for compound $\mathbf{9}$. In fact, it shows a weaker chemical hardness than benomyl, this means that benomyl is more resistant to the charge transfer and thus less reactive than compound 9. On the other hand, the values of $\sigma$, $\chi, \mu$ and $\omega$ also denote a reactivity for compound $\mathbf{9}$ higher than for benomyl, which nicely correlates with the experimental antifungal findings. 
Table 4. Calculated quantum chemical parameters for compound 9 and benomyl.

\begin{tabular}{lcc}
\hline \multicolumn{1}{c}{ Chemical reactivity indices $(\mathrm{eV})$} & $\mathbf{9}$ & Benomyl \\
\hline$E_{\mathrm{HOMO}}$ & -5.768 & -5.822 \\
$E_{\mathrm{LUMO}}$ & -1.550 & -0.519 \\
$\Delta E=E_{\mathrm{LUMO}}-E_{\mathrm{HOMO}}$ & 4.218 & 5.303 \\
Chemical hardness $\left(\eta=\left(E_{\mathrm{LUMO}}-E_{\mathrm{HOMO}}\right) / 2\right)$ & 2.109 & 2.651 \\
Softness $(\sigma=1 / \eta)$ & 0.474 & 0.377 \\
Electronegativity $\left(\chi=-\left(E_{\mathrm{LUMO}}+E_{\mathrm{HOMO}}\right) / 2\right)$ & 3.659 & 3.170 \\
Chemical potential $(\mu=-\chi)$ & -3.659 & -3.170 \\
Electrophilicity index $\left(\omega=\mu^{2} / 2 \eta\right)$ & 3.174 & 2.525 \\
\hline
\end{tabular}

Finally, a molecular electrostatic potential (MEP) investigation was carried out in order to identify and predict the reactive sites for nucleophilic and electrophilic attacks. MEP is commonly used to understand the biological recognition processes and hydrogen bonding interactions. ${ }^{57}$ The MEP plots have been generated for the DFT optimized geometries of compound $\mathbf{9}$ and benomyl, and they are given in Figure 5.
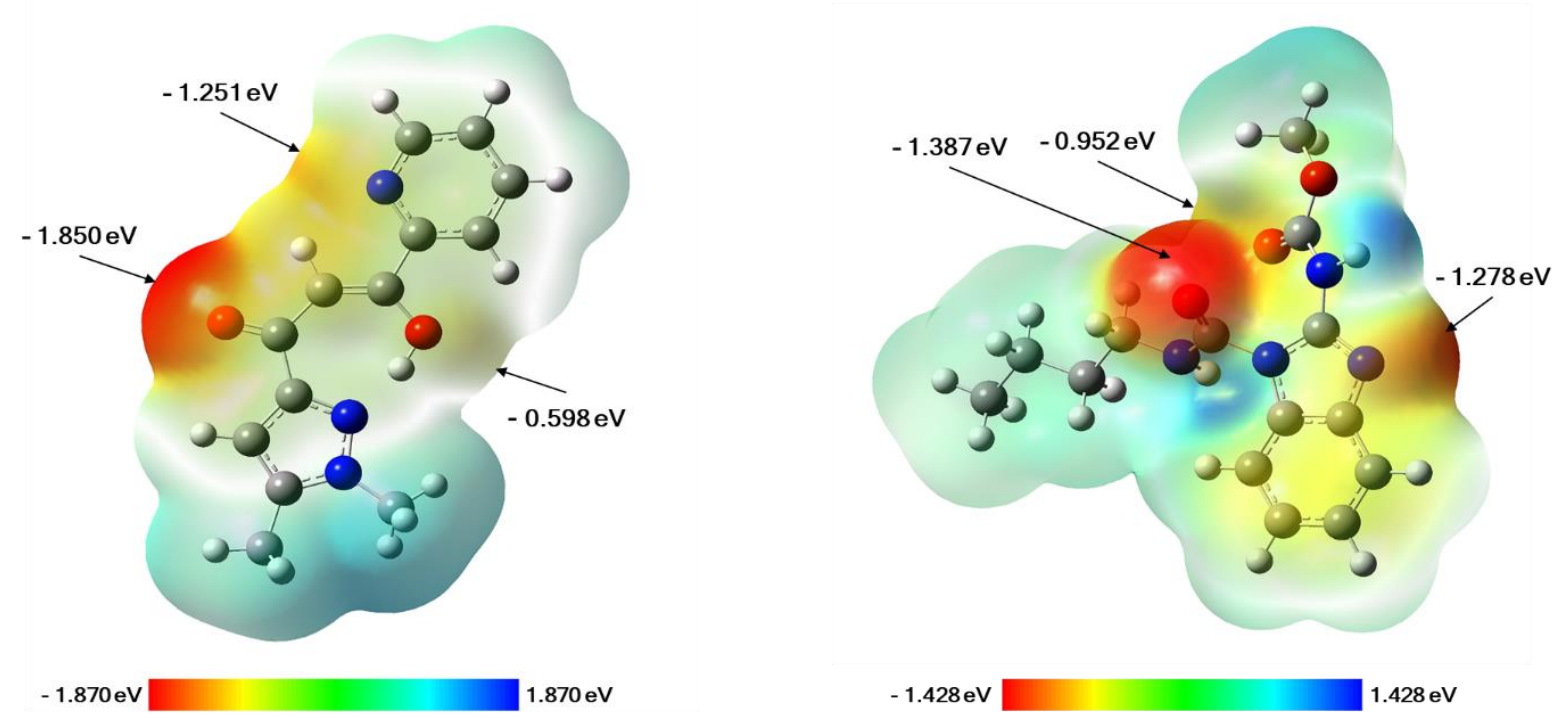

Figure 5. Molecular electrostatic potential (MEP) maps of compound 9 (left) and benomyl (right).

The electrostatic potential at the surface increases in the order red $<$ orange $<$ yellow $<$ green $<$ blue (see in Figure 5). It varies from negative regions (red, orange and yellow) related to electrophilic reactivity towards positive regions (green and blue) which represent the nucleophilic reactivity. For compound 9, the negative electrostatic potential regions are mainly centered over the oxygen atoms of the $\beta$-keto-enol pharmacophore and the nitrogen atom of pyridine with values varying from -0.598 to $-1.850 \mathrm{eV}$, while the positive regions are localized 
on the $\mathrm{CH}_{3}$ groups of the pyrazole ring. For benomyl, the map shows negative values from 0.952 to $-1.387 \mathrm{eV}$ mainly centered over the oxygen atoms of carbonyl groups $(\mathrm{C}=\mathrm{O})$ and the unsubstituted nitrogen atom of the benzimidazole ring while the positive values are focused over the NH groups.

\subsubsection{Homology modeling}

As described previously, all the prepared compounds containing $\beta$-keto-enol pharmacophore site and important azole therapeutic moiety (pyrazole). And as is known, these groups act on the cell membrane of microorganisms. This fact encourages us to postulate that our compounds can interact with specific targets located on the membrane of the studied fungal. While, it is well established that fungal cell membranes and cell walls are of particular importance in the development of antifungal drugs. ${ }^{58}$ based on these considerations, Fusarium oxysporum Guanine nucleotide-binding protein beta (Fgb1) was chosen as a target in the present work. Actually, this protein is one of the most important membrane proteins and it is implicated in several biological processes of $F$. oxysporum fungal, which make it a potential target to develop new inhibitors. ${ }^{59-60}$ Unfortunately, till now there is no experimental structure of this protein in the Protein Data Bank. For these reasons, a homology study was performed to build a threedimensional structure of this protein based on an already known structure following the procedure described in our previous work. ${ }^{38}$ Briefly, the Fgb1 primary residues sequence (accession number Q96VA6) was used as a target. A BLASTp search was carried out to find a suitable template with already known 3D structure for this amino acid sequence. With a similarity of $67 \%$ to Fgb1 sequence, the 3SN6_chain B (Rattus norvegicus Guanine nucleotidebinding protein $\mathrm{G}(\mathrm{I}) / \mathrm{G}(\mathrm{S}) / \mathrm{G}(\mathrm{T})$ subunit beta-1) was identified as the best template. Sequence alignment performed between the target and the template, revealing a total conservation of $63.23 \%$ of residues (227 residues), strong similarity of $15.04 \%$ (54 residues) and weak identity of 5.30\% (19 residues) (Supporting Information (SI), Figure S1). While, 59 amino acids (16.43\%) of the FGB1 were found non-matching those of the selected template. based on the obtained aligned sequence; a 3D model was generated for the Fgb1 protein (SI, Figure S2). Then the PROCHECK suite was utilized to check the quality of this model. Superimposing the generated model on the template backbone (3SN6_ chain B experimental structure) results in a very low RMS deviation of $0.257 \AA$ between their main chain atoms. The Ramachandran plot was used to evaluate the structure quality by visualizing the energetically allowed regions, it provides the amount of residues belonging to the favored (>90\%), additional allowed, 
generously allowed and disallowed regions. As can be seen from Figure 6, the majority of the amino acid residues are located in the most favored regions (red color) of the phi-psi distribution with a percentage of $90.9 \%$. While $7.2 \%, 1.3 \%$ and $0.7 \%$ of residues were found to locate the additional allowed (yellow color), generously allowed (light yellow color) and the disallowed regions (white color) respectively which is very comparable with the values obtained with the experimental structure of the used template $(92.5 \%$ of residues are in the most favored regions, $6.7 \%$ for additional allowed regions, $0.7 \%$ for generously allowed regions and $0.0 \%$ for the disallowed regions). Additionally, the mean G-factor takes respectively the values of -0.21 and 0.11 for the generated model and the template, both placed in the optimal region (values below -0.5 are unusual). In conclusion, all these parameters attest reliability and good quality for the generated model of the Fgb1 protein.

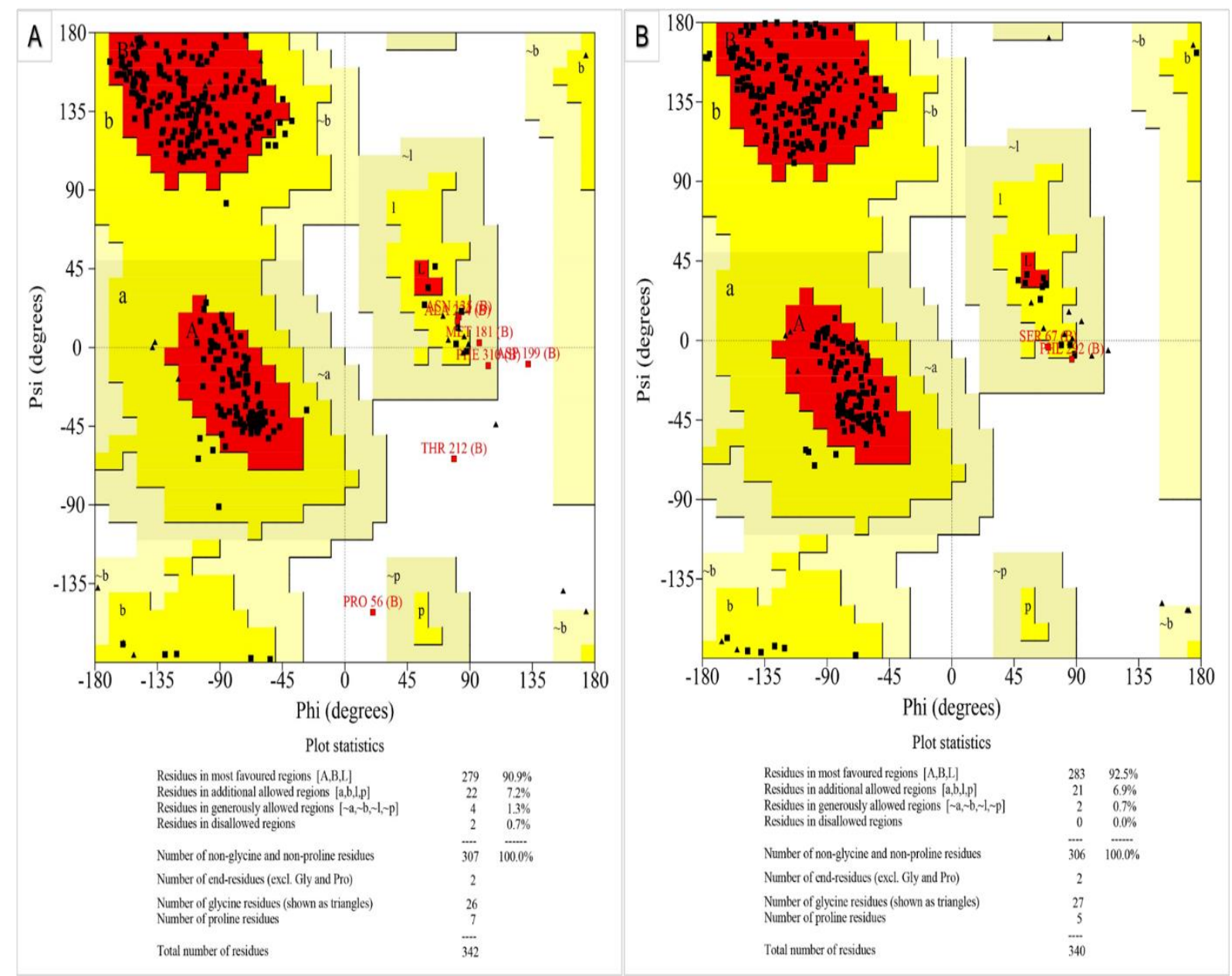

Figure 6. Ramachandran plot analysis of (A) the generated Fgb1 model and (B) the template model 3SN6_chain B. 


\subsubsection{Molecular docking}

In the present work, to rationalize the antifungal results obtained and to investigate the most probable binding mode, the modeled Fgb1 protein was targeted to perform a docking study of benomyl and of the most active compound 9 of the $\beta$-keto-enol pyrazolic series. The binding energy $\Delta \mathrm{G}_{\text {binding }}$, the $\mathrm{H}$-bonds and their lengths have been used to evaluate the binding affinity of each molecule to Fgb1 protein. The most negative value of $\Delta \mathrm{G}_{\text {binding }}$ corresponds to the most stable ligand-receptor complex, giving valuable information about the most active compound. The calculated parameters have been reported in Table 5.

Table 5. Intermolecular interactions between the ligands docked with Fgb1.

\begin{tabular}{cclc}
\hline Compound & $\boldsymbol{\Delta}$ Gbinding $(\mathbf{k c a l} / \mathbf{m o l})$ & Hydrogen bond & Bond length $(\AA)$ \\
\hline \multirow{3}{*}{9} & \multirow{3}{*}{-7.161} & $\mathrm{~N} 1($ pyrazole $)-\operatorname{Arg} 167$ & 1.73 \\
& & $\mathrm{~N} 1($ pyrazole $)-\operatorname{Arg} 167$ & 2.82 \\
& & $\mathrm{O}(\mathrm{OH})-\mathrm{Gln} 251$ & 2.21 \\
& $\mathrm{O}(\mathrm{C}=\mathrm{O})-\mathrm{Val} 338$ & 2.58 \\
\hline \multirow{3}{*}{ Benomyl } & \multirow{3}{*}{-6.985} & $\mathrm{O}(\mathrm{C}=\mathrm{O})-\mathrm{Leu} 209$ & 2.17 \\
& & $\mathrm{O}(\mathrm{C}=\mathrm{O})-\mathrm{Thr} 212$ & 2.35 \\
& & $\mathrm{~N} 3($ benzimidazole $)-\mathrm{Gln} 251$ & 2.46 \\
\hline
\end{tabular}

According to in silico protein-ligand calculations, with a binding score of $-7.461 \mathrm{kcal} / \mathrm{mol}$, the compound 9 is found better complexed with the Fgb1 receptor than benomyl (binding score of $-6.985 \mathrm{kcal} / \mathrm{mol}$ ). Based on this finding, compound 9 seems more active than benomyl, which is in total accordance with the experimental antifungal measurements.

As depicted in Figure 7, compound 9 and benomyl can both form many hydrogen bonds with the active site residues of the Fgb1 protein. Compound 9 makes four H-bonds with the protein: two bonds of 1.73 and $2.82 \AA$ between the $\mathrm{N} 1$ atom of pyrazole and the amino acid residue Arg167, one bond of $2.21 \AA$ between the $\mathrm{O}$ atom of the alcohol function and the Gln251 residue and one bond of $2.58 \AA$ A between the $\mathrm{O}$ atom of the carbonyl group $(\mathrm{C}=\mathrm{O})$ and the $\mathrm{Val} 338$ residue. The molecule of benomyl (standard drug) shows interactions with the Leu209 (2.17 $\AA$ ), Thr212 (2.35 $\AA$ ) and Gln251 (2.46 $)$ residues through respectively the two carbonyl groups and the $\mathrm{N} 3$ atom of the benzimidazole ring. Interestingly, a good correlation is found between our docking results and the electronic calculations discussed above. In fact, the interactions between the studied molecules and the amino acid residues of the receptor Fgb1, occur at the high electron density regions of the molecule identified previously by the MEP maps. However, 
more theoretical calculations and/or experiment investigations are required to confirm the validity of these docking results.

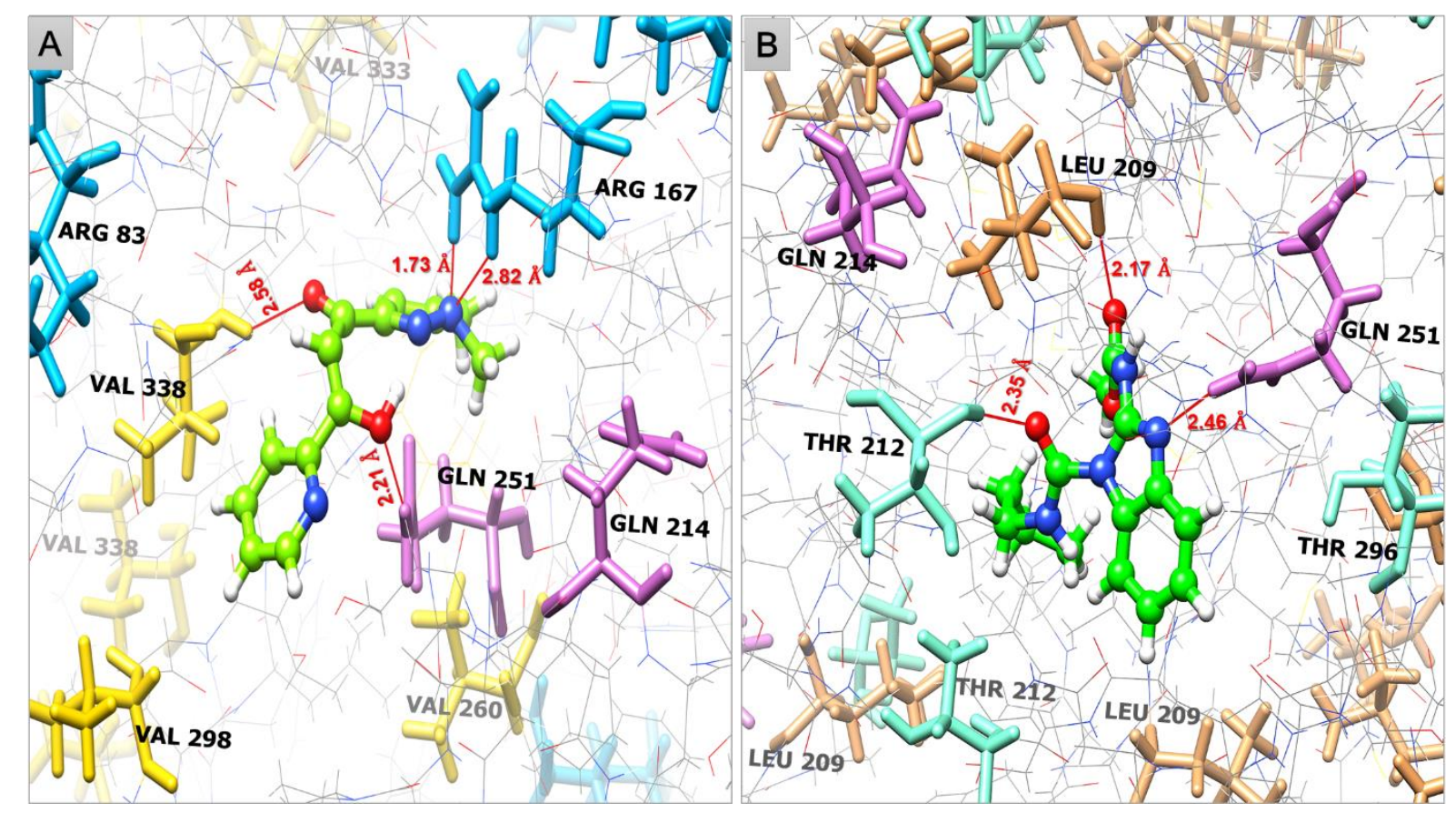

Figure 7. Binding mode of compound 9 (A) and benomyl (B) into the active pocket of the Fgb1 protein.

In addition, the influence of protonation states and tautomeric forms on virtual screening results has been well established and an extensive research was made in this field. ${ }^{61-65}$ It can influence the hydrogen bonding ability of the ligand to the receptor. In this context, and in order to investigate the possible effects of both these phenomena during our docking simulation, the tautomeric form (9t) and the protonated state $(\mathbf{9 p})$ at the physiological $\mathrm{pH}(\mathrm{pH}=7-8)$ of compound 9 were docked against the same Fgb1 protein model used previously. The docking results are summarized and displayed in Table S1 and Figure S3 in Supporting Information. With a binding score of $-6.780 \mathrm{kcal} / \mathrm{mol}$, the best pose of the tautomeric form (9t) was found to be linked to the active pocket of Fgb1 by three bonds involving the amino acid residues Ser206, Thr118 and Cys 165 with distances of $2.33 \AA, 2.74 \AA$ and $2.76 \AA$, respectively. While, in protonated form (9p) docking result (Figure S3B) indicates that Asn340 and Gln251 formed hydrogen bonds with $\mathrm{O}^{-}\left(\mathrm{C}^{-} \mathrm{O}^{-}\right)$and $\mathrm{N} 2$ (pyrazole) respectively. The distances were found to be $2.23 \AA$ with Asn 340 and $2.43 \AA$ with Gln251. Furthermore, through comparing the binding energies of the three forms, it was found that the enol form (9) has slightly better binding score value in comparison with the keto isomer $(\mathbf{9 t})$ and the protonated form $(\mathbf{9 p})$ due to the presence of more polar properties and more interaction with protein in the case of the enol tautomeric. ${ }^{66}$ However, it is important to mention that the calculated binding energies do not always reflect 
the biological response, ${ }^{67}$ and also none of the compounds $9 \mathbf{t}$ and $9 \mathbf{p}$ has tested in vitro against the studied fungal.

Finally, these important observations open up the way for investigation into various structural and chemical modifications in order to make our compounds even more efficient. Furthermore, within the general context of development of new anti-Fusarium agents targeting proteins and specially Fgb1, additional suitable experimental assays are required to confirm the good capacity of these active compounds.

\section{Conclusion}

This manuscript described the first synthesis of novel $\beta$-keto-enol embedded with pyrazolic moiety compounds, and evaluated their in vitro antifungal activities. Some of the prepared compounds show better antifungal activity than the reference. Interestingly, compounds $\mathbf{2}$ and 9 display $96 \%$ antifungal activity which is even better than the benomyl fungicide reference. DFT calculations were performed to determine the reactivity of the most active compound i.e. compound 9 and of benomyl and to demonstrate the correlation with our experimental results. Furthermore, molecular docking study was carried out to determine the binding mode of compound 9 and benomyl into the Fgb1 protein pocket. The possible effects of ligand protonation and tautomeric states on the docking simulation results were also investigated for the compound 9. Hopefully, the obtained results in this study will present a guideline to facilitate a better understanding of the mode of action of ligand-enzyme complex and give a clear insight to design new molecules in the future. However, appropriate in vitro experiments on the inhibition of Fgb1 with the novel $\beta$-keto-enol pyrazolic compounds should be performed in the future and their interaction should be identified by others performing methods such as molecular dynamics simulations and free-energy calculations.

\section{Author Information}

\section{Corresponding Authors}

*E-mail: (S. Radi) s.radi@ump.ac.ma

*E-mail: (F . Abrigach) : abrigach.farid@live.fr

\section{ORCID:}

Smaail Radi : 0000-0002-5062-6904

Farid Abrigach : 0000-0001-8062-7572

Monique Tillard : 0000-0002-0609-7224 


\section{Notes}

The authors declare no competing financial interest.

\section{Acknowledgments}

The authors extend their appreciation to the PPR2-MESRSFC-CNRST-P10 project (Morocco) for supporting this work.

\section{Supporting Information}

The supporting data contains further information related to the homology modeling (Sequence alignment between Fgb1 (F. oxysporum) and the template (3SN6_chain B) (Figure S1), the 3D structure of the generated homology model (Figure S2)) and the docking simulation (results of docking study and the 3D representation of the interactions between compounds $9 t$ and $9 p$ and the active pocked residues of Fgb1 protein).

This information is available free of charge via the Internet at http://pubs.acs.org

\section{References}

1. Egbertson, M. S.; Anthony, N. J.; Summa, V., HIV Integrase Inhibitors: From Diketo Acids to Heterocyclic Templates: History of HIV Integrase Medicinal Chemistry at Merck West Point and Merck Rome (IRBM) Leading to Discovery of Raltegravir. In HIV - 1 Integrase: Mechanism and Inhibitor Design, Neamati, N., Ed. John Wiley \& Sons 2011; pp 197-229.

2. Pommier, Y.; Johnson, A. A.; Marchand, C., Integrase Inhibitors to Treat HIV/AIDS. Nat. Rev. Drug Discovery 2005, 4, 236.

3. Goldgur, Y.; Craigie, R.; Cohen, G. H.; Fujiwara, T.; Yoshinaga, T.; Fujishita, T.; Sugimoto, H.; Endo, T.; Murai, H.; Davies, D. R., Structure of the HIV-1 Integrase Catalytic Domain Complexed with an Inhibitor: A Platform For Antiviral Drug Design. Proc. Natl. Acad. Sci. U. S. A. 1999, 96, 13040-13043.

4. Hazuda, D. J.; Felock, P.; Witmer, M.; Wolfe, A.; Stillmock, K.; Grobler, J. A.; Espeseth, A.; Gabryelski, L.; Schleif, W.; Blau, C.; Miller, M. D., Inhibitors of Strand Transfer That Prevent Integration and Inhibit HIV-1 Replication in Cells. Science 2000, 287, 646-650.

5. Ishikawa, Y.; Fujii, S., Binding Mode Prediction and Inhibitor Design of Anti-Influenza Virus Diketo Acids Targeting Metalloenzyme RNA Polymerase by Molecular Docking. Bioinformation 2011, 6, 221-225.

6. Chattopadhyay, I.; Biswas, K.; Bandyopadhyay, U.; Banerjee, R. K., Turmeric and Curcumin: Biological Actions and Medicinal Applications. Curr. Sci. 2004, 87 44-53.

7. Anand, P.; Thomas, S. G.; Kunnumakkara, A. B.; Sundaram, C.; Harikumar, K. B.; Sung, B.; Tharakan, S. T.; Misra, K.; Priyadarsini, I. K.; Rajasekharan, K. N.; Aggarwal, B. B., Biological Activities of Curcumin and Its Analogues (Congeners) Made by Man and Mother Nature. Biochem. Pharmacol. 2008, 76, 1590-1611.

8. Furlan, V.; Konc, J.; Bren, U., Inverse Molecular Docking as a Novel Approach to Study Anticarcinogenic and Anti-Neuroinflammatory Effects of Curcumin. Molecules 2018, 23, 3351. 
9. Brglez Mojzer, E.; Knez Hrnčič, M.; Škerget, M.; Knez, Ž.; Bren, U., Polyphenols: Extraction Methods, Antioxidative Action, Bioavailability and Anticarcinogenic Effects. Molecules 2016, 21, 901.

10. Kohyama, A.; Yamakoshi, H.; Hongo, S.; Kanoh, N.; Shibata, H.; Iwabuchi, Y., StructureActivity Relationships of the Antitumor C5-Curcuminoid GO-Y030. Molecules 2015, 20, 15374-15391.

11. Tan, K.-L.; Ali, A.; Du, Y.; Fu, H.; Jin, H.-X.; Chin, T.-M.; Khan, M.; Go, M.-L., Synthesis and Evaluation of Bisbenzylidenedioxotetrahydrothiopranones as Activators of Endoplasmic Reticulum (ER) Stress Signaling Pathways and Apoptotic Cell Death in Acute Promyelocytic Leukemic Cells. J. Med. Chem. 2014, 57, 5904-5918.

12. Liang, G.; Shao, L.; Wang, Y.; Zhao, C.; Chu, Y.; Xiao, J.; Zhao, Y.; Li, X.; Yang, S., Exploration and Synthesis of Curcumin Analogues with Improved Structural Stability Both In vitro and In vivo as Cytotoxic Agents. Biorg. Med. Chem. 2009, 17, 2623-2631.

13. Adams, B. K.; Cai, J.; Armstrong, J.; Herold, M.; Lu, Y. J.; Sun, A.; Snyder, J. P.; Liotta, D. C.; Jones, D. P.; Shoji, M., EF24, A Novel Synthetic Curcumin Analog, Induces Apoptosis in Cancer Cells via a Redox-Dependent Mechanism. Anticancer. Drugs 2005, $16,263-275$.

14. Minassi, A.; Sánchez-Duffhues, G.; Collado, J. A.; Muñoz, E.; Appendino, G., Dissecting the Pharmacophore of Curcumin. Which Structural Element Is Critical for Which Action? J. Nat. Prod. 2013, 76, 1105-1112.

15. Liang, G.; Li, X.; Chen, L.; Yang, S.; Wu, X.; Studer, E.; Gurley, E.; Hylemon, P. B.; Ye, F.; Li, Y.; Zhou, H., Synthesis and Anti-Inflammatory Activities of Mono-carbonyl Analogues of Curcumin. Biorg. Med. Chem. Lett. 2008, 18, 1525-1529.

16. Agrawal, D. K.; Mishra, P. K., Curcumin and its Analogues: Potential Anticancer Agents. Med. Res. Rev. 2010, 30, 818-60.

17. Radi, S.; Tighadouini, S.; Feron, O.; Riant, O.; Bouakka, M.; Benabbes, R.; Mabkhot, N. Y., Synthesis of Novel $\beta$-Keto-Enol Derivatives Tethered Pyrazole, Pyridine and Furan as New Potential Antifungal and Anti-Breast Cancer Agents. Molecules 2015, 20, 2018620194.

18. Song, W.-H.; Liu, M.-M.; Zhong, D.-W.; Zhu, Y.-l.; Bosscher, M.; Zhou, L.; Ye, D.-Y.; Yuan, Z.-H., Tetrazole and Triazole as Bioisosteres of Carboxylic Acid: Discovery of Diketo Tetrazoles and Diketo Triazoles as Anti-HCV Agents. Biorg. Med. Chem. Lett. 2013, 23, 4528-4531.

19. Luo, Z.-G.; Zhao, Y.; Ma, C.; Xu, X.-M.; Zhang, X.-M.; Huang, N.-Y.; He, H.-Q., Synthesis and Anti-Integrase Evaluation of Novel Calix[4]arene Derivatives Containing the Triazolyl 1,3-diketo Moiety. Chin. Chem. Lett. 2014, 25, 737-740.

20. Patel, K.; Karthikeyan, C.; Raja Solomon, V.; S. Hari Narayana Moorthy, N.; Lee, H.; Sahu, K.; Singh Deora, G.; Trivedi, P., Synthesis of Some Coumarinyl Chalcones and Their Antiproliferative Activity Against Breast Cancer Cell Lines. Lett. Drug Des. Discovery 2011, 8, 308-311.

21. Prieto-Martínez, F. D.; Arciniega, M.; Medina-Franco, J. L., Molecular Docking: Current Advances and Challenges. TIP Rev.Esp.Cienc.Quím.Biol. 2018, 21, 65-87.

22. Radi, S.; Tighadouini, S.; Eddike, D.; Tillard, M.; Mabkhot Yahia, N., Crystal Structure of (Z)-1-(1,5-dimethyl-1H-pyrazol-3-yl)-3-hydroxy-3-(4-methoxyphenyl)prop-2-en-1-one, $\mathrm{C}_{15} \mathrm{H}_{16} \mathrm{~N}_{2} \mathrm{O}_{3}$. Z. Kristallogr. - New Cryst. Struct. 2017, 232, 199-200.

23. Radi, S.; Tighadouini, S.; Eddike, D.; Tillard, M.; Mabkhot Yahia, N., Crystal Structure of (Z)-1-(1,5-dimethyl-1H-pyrazol-3-yl)-3-hydroxy-3-phenylprop-2-en-1-one, $\mathrm{C}_{14} \mathrm{H}_{14} \mathrm{~N}_{2} \mathrm{O}_{2}$. Z. Kristallogr. - New Cryst. Struct. 2017, 232, 201-202. 
24. Radi, S.; Tighadouini, S.; Eddike, D.; Tillard, M.; Mabkhot Yahia, N., Crystal Structure of (Z)-1-(1,5-dimethyl-1H-pyrazol-3-yl)-3-(4-ethoxyphenyl)-3-hydroxyprop-2-en-1-one, $\mathrm{C}_{16} \mathrm{H}_{18} \mathrm{~N}_{2} \mathrm{O}_{3}$. Z. Kristallogr. - New Cryst. Struct. 2017, 232, 207-208.

25. Radi, S.; Tighadouini, S.; Eddike, D.; Tillard, M.; Mabkhot Yahia, N., Crystal Structure of (Z)-1-(1,5-dimethyl-1H-pyrazol-3-yl)-3-hydroxy-3-(p-toly)prop-2-en-1-one, $\mathrm{C}_{15} \mathrm{H}_{16} \mathrm{~N}_{2} \mathrm{O}_{2}$. Z. Kristallogr. - New Cryst. Struct. 2017, 232, 209-210.

26. Radi, S.; Tighadouini, S.; Eddike, D.; Mabkhot Yahia, N.; Tillard, M., Crystal Structure of (Z)-3-hydroxy-3-(4-methoxyphenyl)-1-(pyridin-2-yl)prop-2-en-1-one, $\quad \mathrm{C}_{15} \mathrm{H}_{13} \mathrm{NO}_{3} . \quad Z$. Kristallogr. - New Cryst. Struct. 2017, 232, 235-236.

27. Radi, S.; Tighadouini, S.; Bacquet, M.; Degoutin, S.; Dacquin, J.-P.; Eddike, D.; Tillard, M.; Mabkhot, Y., $\beta$-Keto-enol Tethered Pyridine and Thiophene: Synthesis, Crystal Structure Determination and Its Organic Immobilization on Silica for Efficient SolidLiquid Extraction of Heavy Metals. Molecules 2016, 21, 888.

28. Tighadouini, S.; Radi, S.; Bacquet, M.; Degoutin, S.; Zaghrioui, M.; Jodeh, S.; Warad, I., Removal Efficiency of $\mathrm{Pb}$ (II), Zn (II), Cd (II) and $\mathrm{Cu}$ (II) from Aqueous Solution and Natural Water by Ketoenol-Pyrazole Receptor Functionalized Silica Hybrid Adsorbent. Sep. Sci. Technol. 2017, 52, 608-621.

29. Radi, S.; Tighadouini, S.; Bacquet, M.; Degoutin, S.; Garcia, Y., New Hybrid Material Based on a Silica-Immobilised Conjugated $\beta$-Ketoenol-bipyridine Receptor and Its Excellent $\mathrm{Cu}(\mathrm{II})$ Adsorption Capacity. Anal. Methods 2016, 8, 6923-6931.

30. Radi, S.; Tighadouini, S.; El Massaoudi, M.; Bacquet, M.; Degoutin, S.; Revel, B.; Mabkhot, Y. N., Thermodynamics and Kinetics of Heavy Metals Adsorption on Silica Particles Chemically Modified by Conjugated $\beta$-Ketoenol Furan. J. Chem. Eng. Data 2015, 60, 2915-2925.

31. Radi, S.; Tighadouini, S.; Bacquet, M.; Degoutin, S.; Revel, B.; Zaghrioui, M., Quantitative Removal of $\mathrm{Zn}$ (II) From Aqueous Solution and Natural Water Using New SilicaImmobilized Ketoenol-Pyridine Receptor. J. Environ. Chem. Eng. 2015, 3, 1769-1778.

32. Rigaku Oxford Diffraction, CrysAlisPro Software System, Version 1.171.38.41, Rigaku Corporation, Oxford, UK, 2015.

33. Sheldrick, G. M. SHELXS. A Program for Crystal Structures Solution; SHELXL. A Program for Refining Crystal Structures, University of Göttingen. Germany, 2013.

34. Farrugia, L. J., WinGX and ORTEP for Windows: An Update. J. Appl. Crystallogr. 2012, $45,849-854$.

35. Neri, F.; Mari, M.; Brigati, S., Control of Penicillium Expansum by Plant Volatile Compounds. Plant Pathol. 2006, 55, 100-105.

36. Garrod, L. P.; O'Grady, F., Antibiotic and Chemotherapy. 3rd Edition ed.; Edinburgh, London: E. \& S. Livingstone.: 1972.

37. National Committee for Clinical Laboratory Standards, Performance Standards for Antimicrobial Disk Susceptibility Tests - Sixth Edition; Approved Standard. NCCLS Document M2-A6, Vol. 17, No. 1, NCCLS, 940 West Valley Road, Suite 1400, Wayne, PA. . January 1997.

38. Abrigach, F.; Rokni, Y.; Takfaoui, A.; Khoutoul, M.; Doucet, H.; Asehraou, A.; Touzani, R., In Vitro Screening, Homology Modeling and Molecular Docking Studies of Some Pyrazole and Imidazole Derivatives. Biomed. Pharmacother. 2018, 103, 653-661.

39. ACD/ChemSketch version 12.01; Advanced Chemistry Development, Inc.: Toronto, ON, Canada, 2010. 
40. Frisch, M. J.; Trucks, G. W.; Schlegel, H. B.; Scuseria, G. E.; Robb, M. A.; Cheeseman, J. R.; Scalmani, G.; Barone, V.; Mennucci, B.; Petersson, G. A.; Nakatsuji, H.; Caricato, M.; Li, X.; Hratchian, H. P.; Izmaylov, A. F.; Bloino, J.; Zheng, G.; Sonnenberg, J. L.; Hada, M.; Ehara, M.; Toyota, K.; Fukuda, R.; Hasegawa, J.; Ishida, M.; Nakajima, T.; Honda, Y.; Kitao, O.; Nakai, H.; Vreven, T.; Montgomery Jr., J. A.; Peralta, J. E.; Ogliaro, F.; Bearpark, M. J.; Heyd, J.; Brothers, E. N.; Kudin, K. N.; Staroverov, V. N.; Kobayashi, R.; Normand, J.; Raghavachari, K.; Rendell, A. P.; Burant, J. C.; Iyengar, S. S.; Tomasi, J.; Cossi, M.; Rega, N.; Millam, N. J.; Klene, M.; Knox, J. E.; Cross, J. B.; Bakken, V.; Adamo, C.; Jaramillo, J.; Gomperts, R.; Stratmann, R. E.; Yazyev, O.; Austin, A. J.; Cammi, R.; Pomelli, C.; Ochterski, J. W.; Martin, R. L.; Morokuma, K.; Zakrzewski, V. G.; Voth, G. A.; Salvador, P.; Dannenberg, J. J.; Dapprich, S.; Daniels, A. D.; Farkas, Ö.; Foresman, J. B.; Ortiz, J. V.; Cioslowski, J.; Fox, D. J. Gaussian 09, Gaussian, Inc.: Wallingford, CT, USA, 2009.

41. Grosdidier, A.; Zoete, V.; Michielin, O., SwissDock, A Protein-Small Molecule Docking Web Service Based on EADock DSS. Nucleic Acids Res. 2011, 39, W270-W277.

42. Pettersen, E. F.; Goddard, T. D.; Huang, C. C.; Couch, G. S.; Greenblatt, D. M.; Meng, E. C.; Ferrin, T. E., UCSF Chimera-A Visualization System for Exploratory Research and Analysis. J. Comput. Chem. 2004, 25, 1605-1612.

43. Marvin Sketch was used to determine the protonation state, Marvin 17.1.30 . 2017, ChemAxon (http://www.chemaxon.com) (accessed February 13, 2019).

44. du Plessis, W. C.; Erasmus, J. J. C.; Lamprecht, G. J.; Conradie, J.; Cameron, T. S.; Aquino, M. A. S.; Swarts, J. C., Cyclic Voltammetry of Ferrocene-containing B-diketones as a Tool to Obtain Group Electronegativities. The Structure of 3-ferrocenoyl-1,1,1-trifluoro-2hydroxyprop-2-ene. Can. J. Chem. 1999, 77, 378-386.

45. Groom, C. R.; Bruno, I. J.; Lightfoot, M. P.; Ward, S. C., The Cambridge Structural Database (http://www.ccdc.cam.ac.uk/structures (accessed February 13, 2019)). Acta Crystallogr. B 2016, 72, 171-179.

46. Tighadouini, S.; Radi, S.; Anannaz, M.; Bacquet, M.; Degoutin, S.; Tillard, M.; Eddike, D.; Amhamdi, H.; Garcia, Y., Engineering $\beta$-ketoenol Structure Functionality in Hybrid Silica as Excellent Adsorbent Material for Removal of Heavy Metals from Water. New J. Chem. 2018, 42, 13229-13240.

47. Abrigach, F.; Karzazi, Y.; Benabbes, R.; El Youbi, M.; Khoutoul, M.; Taibi, N.; Karzazi, N.; Benchat, N.; Bouakka, M.; Saalaoui, E.; Touzani, R., Synthesis, Biological Screening, POM, and 3D-QSAR Analyses of Some Novel Pyrazolic Compounds. Med. Chem. Res. 2017, 26, 1784-1795.

48. Hatzade, K.; Sheikh, J.; Taile, V.; Ghatole, A.; Ingle, V.; Genc, M.; Lahsasni, S.; Ben Hadda, T., Antimicrobial/Antioxidant Activity and POM Analyses of Novel 7-O- $\beta-\mathrm{D}-$ glucopyranosyloxy-3-(4, 5-disubstituted imidazol-2-yl)-4H-chromen-4-ones. Med. Chem. Res. 2015, 24, 2679-2693.

49. Tighadouini, S.; Benabbes, R.; Tillard, M.; Eddike, D.; Haboubi, K.; Karrouchi, K.; Radi, S., Synthesis, Crystal Structure, DFT Studies and Biological Activity of (Z)-3-(3bromophenyl)-1-(1,5-dimethyl-1h-pyrazol-3-yl)-3-hydroxyprop-2-en-1-one. Chem. Cent. J. 2018, 12, 122.

50. Demir, P.; Akman, F., Molecular Structure, Spectroscopic Characterization, HOMO and IUMO analysis af PU and PCL Grafted Onto PEMA-co-PHEMA with DFT Quantum Chemical Calculations. J. Mol. Struct. 2017, 1134, 404-415. 
51. Mabkhot, Y. N.; Aldawsari, F. D.; Al-Showiman, S. S.; Barakat, A.; Soliman, S. M.; Choudhary, M. I.; Yousuf, S.; Mubarak, M. S.; Hadda, T. B., Novel Enaminone Derived from Thieno [2,3-b]thiene: Synthesis, X-Ray Crystal Structure, HOMO, LUMO, NBO Analyses and Biological Activity. Chem. Cent. J. 2015, 9, 24.

52. Khoutoul, M.; Djedouani, A.; Lamsayah, M.; Abrigach, F.; Touzani, R., Liquid-Liquid Extraction of Metal Ions, DFT and TD-DFT Analysis for Some Pyrane Derivatives with High Selectivity For Fe(II) and Pb(II). Sep. Sci. Technol. 2016, 51, 1112-1123.

53. Kumar, S.; Saini, V.; Maurya, I. K.; Sindhu, J.; Kumari, M.; Kataria, R.; Kumar, V., Design, Synthesis, DFT, Docking Studies and ADME Prediction of Some New Coumarinyl Linked Pyrazolylthiazoles: Potential Standalone or Adjuvant Antimicrobial Agents. PLoS ONE 2018, 13, e0196016.

54. Kaya, S.; Kaya, C., A New Equation for Calculation of Chemical Hardness of Groups and Molecules. Mol. Phys. 2015, 113, 1311-1319.

55. Gázquez, J. L., Hardness and Softness in Density Functional Theory. In Chemical Hardness, Sen, K. D., Ed. Springer Berlin Heidelberg: Berlin, Heidelberg, 1993; pp 27-43.

56. Parr, R. G.; Szentpály, L. v.; Liu, S., Electrophilicity Index. JACS 1999, 121, 1922-1924.

57. Panicker, C. Y.; Varghese, H. T.; Manjula, P. S.; Sarojini, B. K.; Narayana, B.; War, J. A.; Srivastava, S. K.; Van Alsenoy, C.; Al-Saadi, A. A., FT-IR, HOMO-LUMO, NBO, MEP Analysis and Molecular Docking Study of 3-methyl-4-\{(E)-[4-(methylsulfanyl)benzylidene]amino 1 H-1,2,4-triazole-5(4H)-thione. Spectrochim. Acta. A. Mol. Biomol. Spectrosc. 2015, 151, 198-207.

58. Rautenbach, M.; Troskie, A. M.; Vosloo, J. A., Antifungal Peptides: To Be or Not to Be Membrane Active. Biochimie 2016, 130, 132-145.

59. Lengeler, K. B.; Davidson, R. C.; D'Souza, C.; Harashima, T.; Shen, W.-C.; Wang, P.; Pan, X.; Waugh, M.; Heitman, J., Signal Transduction Cascades Regulating Fungal Development and Virulence. Microbiol. Mol. Biol. Rev. 2000, 64, 746-785.

60. Soundararajan, P.; Sakkiah, S.; Sivanesan, I.; Lee, K.-W.; Jeong, B.-R., Macromolecular Docking Simulation to Identify Binding Site of FGB1 for Antifungal Compounds. Bull. Korean Chem. Soc. 2011, 32 (10), 3675-3681.

61. Martin, Y. C., Let's Not Forget Tautomers. J. Comput. Aided. Mol. Des. 2009, 23, 693-704.

62. Knox, A. J.; Meegan, M. J.; Carta, G.; Lloyd, D. G., Considerations in compound database preparation--"hidden" impact on virtual screening results. J. Chem. Inf. Model. 2005, 45, 1908-1919.

63. Kim, M. O.; Nichols, S. E.; Wang, Y.; McCammon, J. A., Effects of Histidine Protonation and Rotameric States on Virtual Screening of M. tuberculosis RmlC. J. Comput. Aided. Mol. Des. 2013, 27, 235-246.

64. ten Brink, T.; Exner, T. E., Influence of protonation, tautomeric, and stereoisomeric states on protein-ligand docking results. J. Chem. Inf. Model. 2009, 49, 1535-1546.

65. Kalliokoski, T.; Salo, H. S.; Lahtela-Kakkonen, M.; Poso, A., The effect of ligand-based tautomer and protomer prediction on structure-based virtual screening. J. Chem. Inf. Model. 2009, 49, 2742-2748.

66. Kumar, A.; Bora, U., In silico Inhibition Studies of NF- $\kappa$ B p50 Subunit by Curcumin and its Natural Derivatives. Med. Chem. Res. 2011, 21, 3281-3287.

67. Méndez-Cuesta, C. A.; Méndez-Lucio, O.; Castillo, R., Homology Modeling, Docking and Molecular Dynamics of the Leishmania Mexicana Arginase: A Description of the Catalytic Site Useful for Drug Design. J. Mol. Graphics Modell. 2012, 38, 50-59. 